Historic, Archive Document

Do not assume content reflects current scientific knowledge, policies, or practices. 



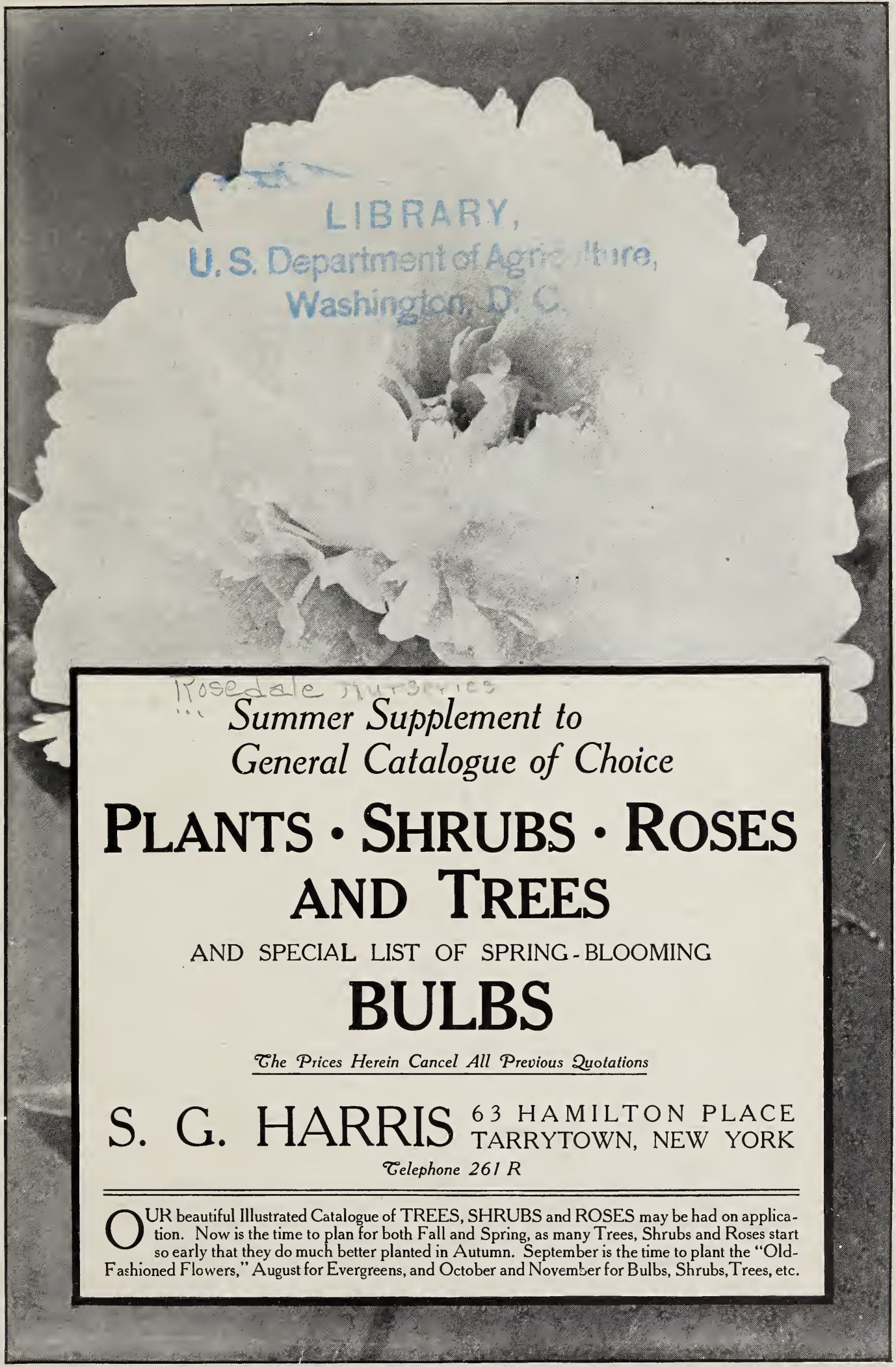




\section{How and When to Plant Bulbs}

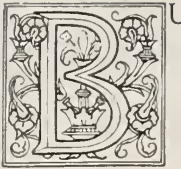

ULB-PLANTING out-of-doors should be as early as the middle of October for best results, and even earlier. In the case of Lilium candidum, Iris, Colchicum and Narcissus, September is none too early. Dutch bulbs should be planted evenly about 6 inches to the bottom of the bulb, in well-prepared soil. Lilies should be 8 to ro inches below the surface. If planted at uneven depths they will not bloom evenly. After the ground is frozen, cover the bed with leaves or stable litter to the depth of 6 inches, and remove it early in spring. Bulbs may be left in the ground and will bloom just as well the second year. If the bed is used for Geraniums, Salvias or other beclding plants (except those with large roots, like Cannas), the bulbs need not be disturbed by setting the plants between them after the blossoms are gone. The leaves of bulbs will soon die down, leaving the bedding plant alone in sight.

It has been my practice, since I began to import bulbs fourteen years ago, to buy for my customers the very best stock grown, believing that Americans are not only as appreciative of the best, but also as able to pay for select bulbs, as are the people of Europe. The result is that I have built up a magnificent trade amid the fiercest competition among large dealers, many of whom have yielded to the cry for cheap bulbs. To secure the low prices at which I offer these choice, picked bulbs, orders should be placed early, as they are filled in rotation. You need not pay, of course, until delivery of the bulbs. My method of securing the best at less than the price for common stock is worth a trial by all who buy bulbs in any quality.

\section{FORCING BULBS}

Tulips in pots make a magnificent display if ten or twelve bulbs of one variety are grown in an 3-inch pot or seed-pan, or seven bulbs in a 6-inch pot. Any good garden soil does very well, but the best consists of three parts of fibrous loam, one part of well-rotted manure and one part sand. Place a piece of broken pot or coal over the hole, fill the pot about two-thirds full of soil, and jar it down somewhat ; set the bulbs on this soil about the same distance apart, and cover them to the depth of an inch, pressing the soil around them firmly with the hand. Soak with water and set the pots away in a dark, cool room, where they should not be allowed to get dry (they may need watering once in two or three weeks); or dig a trench in the garden, set the pots in and cover with coal-ashes to the depth of several inches. Before the ground freezes, place over them a good depth of coarse manure or leaves to keep from freezing, so that the pots may be brought into the house as wanted. Do not bring them into a very warm room.

Hyacinths, Crocuses, Narcissi, etc., should be treated in the same way, except that the crowns of the Hyacinths should not be covered. Hyacinths should be planted singly in 5 -inch pots, or three or four in 7- or 8-inch pots. Successful bulb culture depends upon getting roots well established in the pot at a low temperature of 40 to 50 degrees before bringing them into a temperature of the living-room to form the tops. New pots should soak in water over night before using.

We guarantee our bulbs equal to any imported, no matt.r what claims are made or prices asked

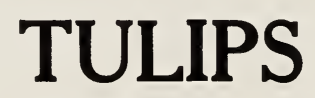

\section{DUC VAN THOL TULIPS}

These Tulips, being the earliest of all, are used for forcing before the others may be flowered. The flowers are smaller than those of other Tulips.

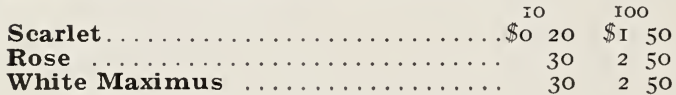

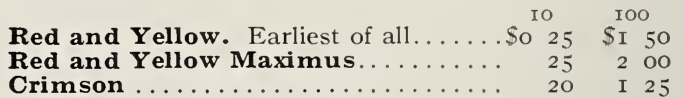

\section{EARLY SINGLE TULIPS}

The following are the cream of the large-flowered varieties. Those marked with a (*) may be forced. All may be used out-of-doors. Letters in the left margin indicate relative time of flowering, A being earlier than $B$. Figures are the height in inches.

B $7 *$ Artus. Scarlet; much used for bedding.

B 9 *Belle Alliance. Scarlet; sweet-scented; large flowers.

A 8 *Canary Bird. Pure yellow

B $9 *$ Chrysolora. Pure yellow; extra fine bedder

B $9 *$ Cottage Maid. White, bordered pink.

B 9 * Couleur de Cardinal. Cardinal-red. .

B 8 * Couleur Ponceau. White, with rosy crimson border

B 7 *Crimson King.

B 9 Duchess de Parma. Red, with yellow border

B $7 *$ Gold Finch. Pure yellow, deliciously fragrant

B 7 * Gold Finch. Pure yellow, deliciously fragrant ............................

B Io *Joost van Vondel. Deep glossy cherry-red and white; large-flowered

$\mathrm{B}$ Io *Keizerkroon. Bright red, with broad yellow edge; extra-large flowers. Very fine for forcing or bedding

8 *king of the Yellows. Very deep golden yellow; extra fine $\ldots \ldots \ldots \ldots$

B $8 *$ La Reine (Queen Victoria). Pure white, slightly tinted with pink. Useful for bedding or forcing.

B $8 *$ L'Immaculee. Pure white; early

B $9 *$ Mon Tresor. Extra fine; pure yellow; large flower. One of the very best.

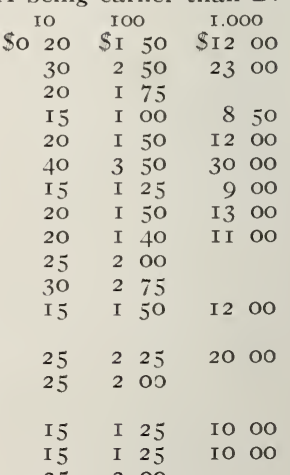


EARLY SINGLE TULIPS, continued

A 9 *Ophir d'Or (Gold of Ophir). Golden yellow. New exhibition variety; fine. $20 \mathrm{cts}$. for IO, \$I .5O per Ioo.

A $8 *$ Pottebakker, White. The best white for forcing. $20 \mathrm{cts}$. for IO, \$I.5O per IOO.

A 8 *Pottebakker, Yellow. $20 \mathrm{cts}$. for IO, \$I.75 per IOO.

A $8 *$ Pottebakker, Scarlet. Bright scarlet; very fine. 30 cts. for Io, $\$ 2.25$ per IOO.

B $9 *$ Prince of Austria. Bright orangevermilion; large, sweet-scented flowers. $40 \mathrm{cts}$. for Io, \$3 per Ioo.

B Io *Princess Wilhelmina. Fine deep pink and white; extra-large flower 30 cts. for IO, \$2.50 per IOO

B 8 *President Lincoln (Queen of the Violets). Extra-fine bedder. 35 cts. for Io, $\$ 3$ per Ioo.

A 7 *Proserpine. Glossy carmine-pink; fine form; very early. $45 \mathrm{cts}$. for IO, $\$ 3.75$ per IOO.

A $8 *$ Rachel Ruisch. White, shaded pink; fine forcer and bedder. $20 \mathrm{cts}$. for IO, \$I.50 per IOO.

A $9 *$ Rembrandt. Fine bright scarlet; very early. $30 \mathrm{cts}$. for I0, \$2.50 per Ioo.

8 Rosa Mundi. Rose and white. $20 \mathrm{c}$ for IO, \$I.50 per IOo.

B $6 *$ Rose Grisdelin. Very fine rosy pink

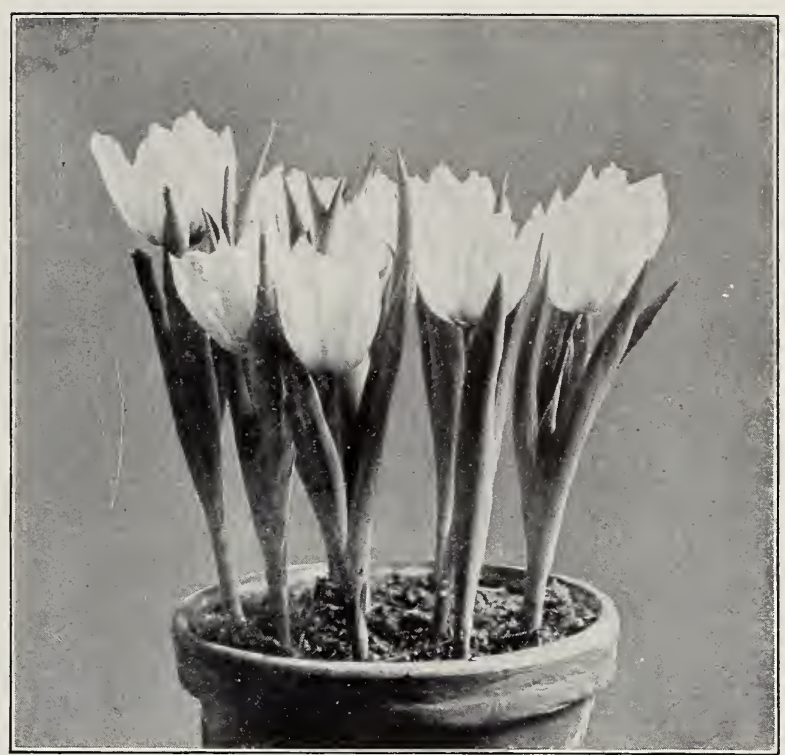

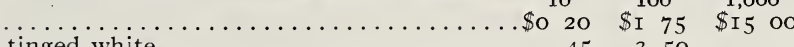

Rose Luisante. Extra-fine dark pink, tinged white $\ldots \ldots \ldots \ldots \ldots \ldots \ldots \ldots \ldots .45 \cdot 350$

8 Standard Royal Silver. White, feathered with cherry-crimson; finest for beds .. $25 \quad 2$ o0

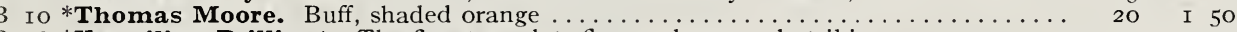

$8 *$ Vermilion Brilliant. The finest scarlet; flowers large and striking ........... $40 \quad 350$

8 White Swan. Pure white; late; blooms with the Couleur de Cardinal. . . . . . . . $25 \quad 25$ oo

6 Wouverman. Purple-violet; fine for out-of-doors $\ldots \ldots \ldots \ldots \ldots \ldots \ldots \ldots \ldots \ldots \ldots . \quad 30 \quad 2 \quad 50$

8 *Yellow Prince. Yellow; sweet-scented. Easily forced; not good for bedding out.. 20 I 25

Fine Mixed Early Single Tulips .... I oo

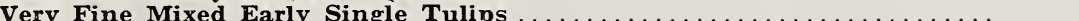

\section{EARLY DOUBLE TULIPS}

No winter-flowering bulbs please my friends more than the Double Tulips. They force very easily.

$9 *$ Couronne des Roses.

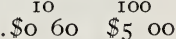

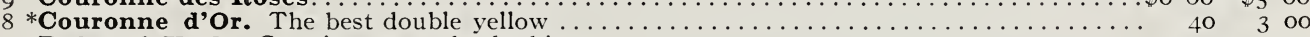

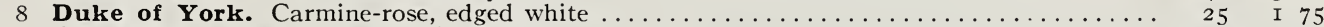

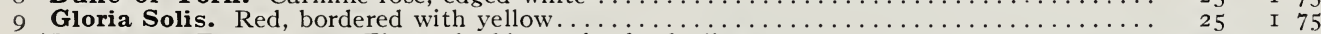

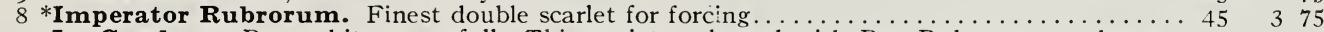

9 La Candeur. Pure white; very full. This variety, planted with Rex Rubrorum, makes a fine effect

$8 *$ Murillo. Magnificent blush-white, suffused with pink; large flowers; superb $\ldots \ldots \ldots \ldots \ldots$

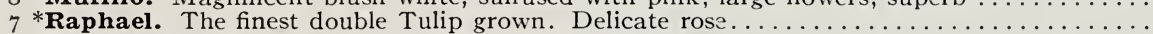

9 Rex Rubrorum. Fine scarlet; large, full, double

7 *Salvator Rosa. Beautiful deep rosy pink. Extra fine for forcing $\ldots \ldots \ldots \ldots \ldots \ldots \ldots \ldots \ldots$

9 *Tournesol, Red. Bordered with yellow. Fine forcer; very large

9 *Tournesol, Yellow. Shaded orange. Fine forcer; large flower

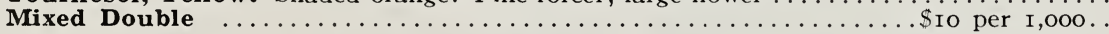

\section{LATE DOUBLE BEDDING TULIPS}

Blue Flag. Bluish violet; distinct and attractive $\ldots \ldots \ldots \ldots \ldots \ldots \ldots \ldots \ldots \ldots \ldots \ldots \ldots \ldots \ldots$ I 75

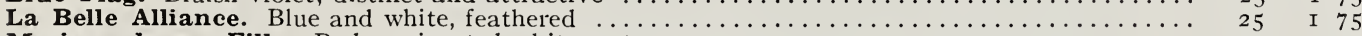

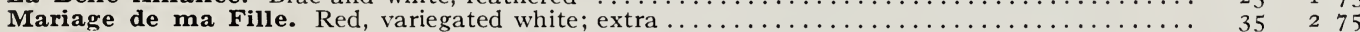

Yellow Rose. Splendid golden yellow; large, full, double.................... 20 I 50

\section{LATE SINGLE BEDDING TULIPS}

No description can do justice to these beautiful Tulips. They bloom much later than the Early Tulips and are exquisite for cutting. They will last in vases for several days. Their popularity is noted by the increasing demand for them. One order of ten brings a larger one the next year. The prices have been quite high, but, at the low rate offered this year, no garden or border should be without them.

Bouton d'Or (Ida). Golden yellow, graceful flowers. Elegant for outdoor cutting until the last of

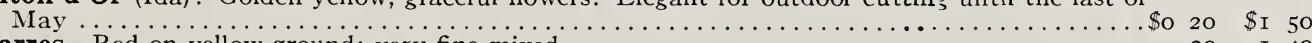

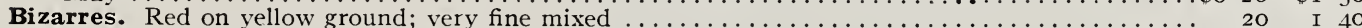

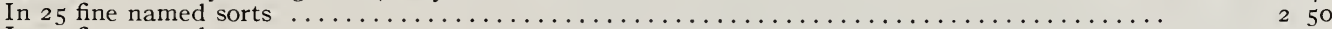

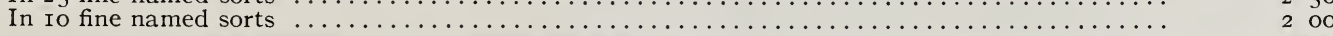


LATE SINGLE BEDDING TULIPS, continued

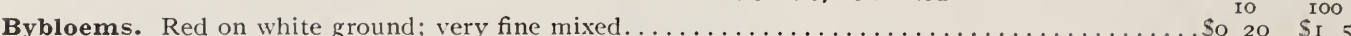

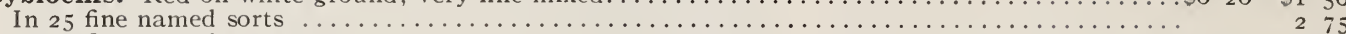

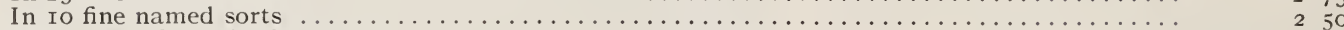

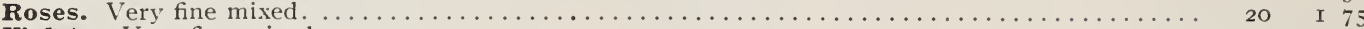

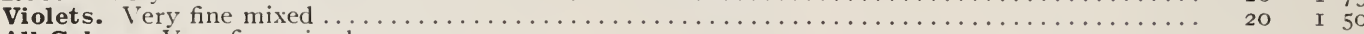

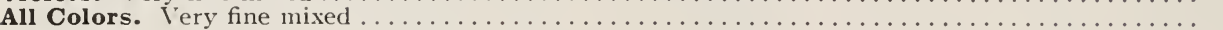

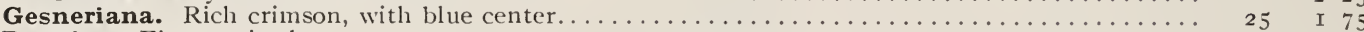

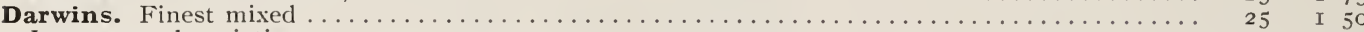

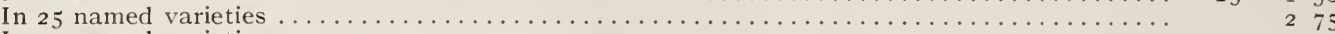

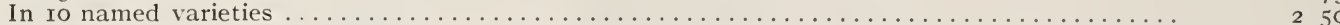

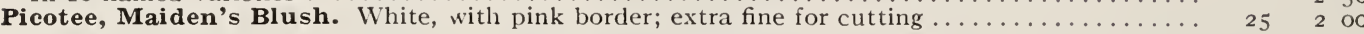

\section{PARROT TULIPS}

The Parrots like a light, sandy soil, shallow planting and a sunny location. Nothing could be more pleasing than these, with their curiously slashed petals and striking color.

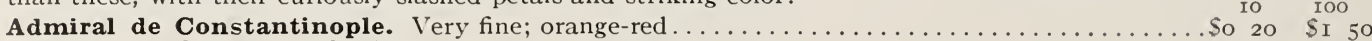

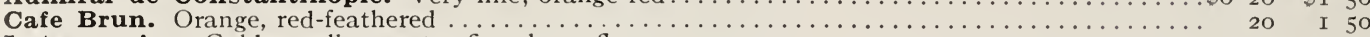

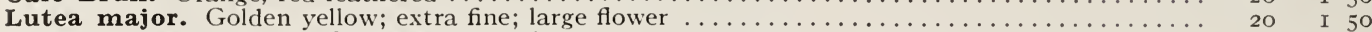

Perfecta. Yellow, scarlet-feathered; extra large $\ldots \ldots \ldots \ldots \ldots \ldots \ldots \ldots \ldots \ldots \ldots \ldots \ldots \ldots \ldots$ I 50

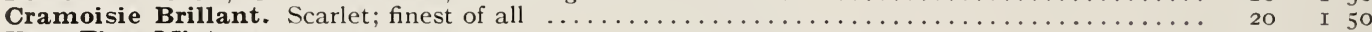

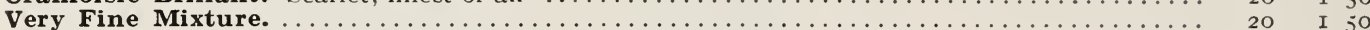

\section{DARWIN TULIPS}

We offer the following superb Darwin Tulips by name to those who wish some of the most striking Tulins known. They grow 2 to 3 feet in height, are of exquisite colors and latest of all Tulips.

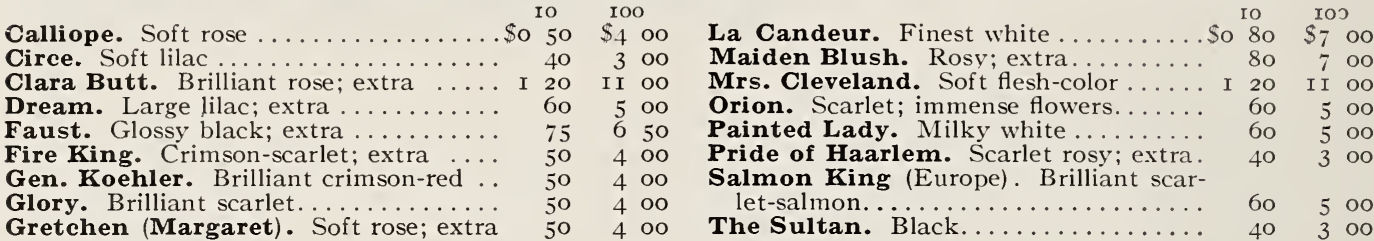

\section{FIRST-SIZE SINGLE HYACINTHS \\ EXTRA-SELECTED}

These fifty kinds are the cream of more than three hundred varieties grown. Being of the best forcing varieties and strictly first-size, they are usually sent out as Exhibition Sizes, Special Collections, etc. The Single Hyacinths have more meritorious habits than the Double. Guaranteed best quality; equal to any imported. In many varieties four bulbs will weigh a pound.

Not less than 4 of a kind at 10, and 25 at 100 rate

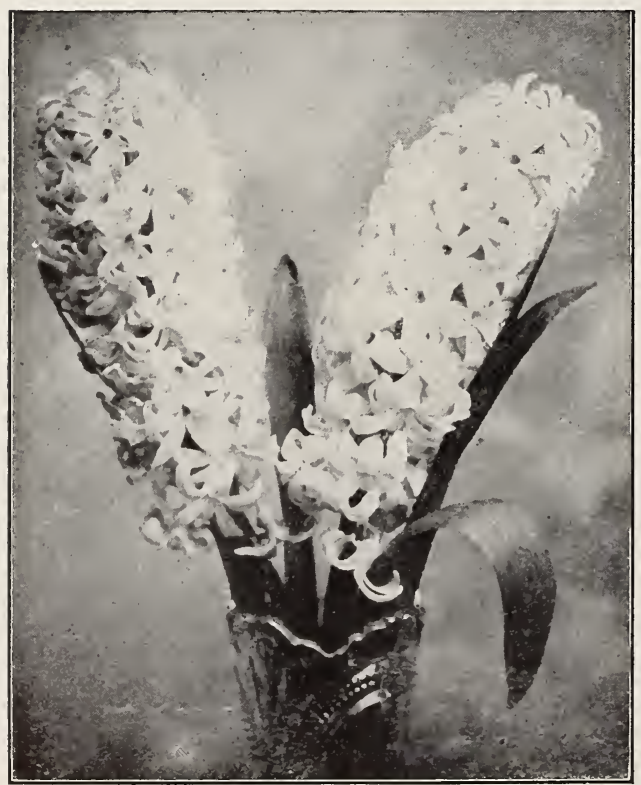

SINGLE HYACINTHS

\section{SINGLE WHITE AND BLUSH}

Alba superbissima. Pure white; large Io roo

Baroness van Thuyll. Very early; pure white; compact truss (the same merit as Baron van Thuyll, pink).

Grandeur a Merveille. Finest blush-white; large truss. There is no better of this color to grow in quantity

La Grandesse. Extra fine; pure white; very large spike; finely formed bells .........

Innocence. Pure white; very large truss. I

Madam Vanderhoop. Pure white; very large bells. This is one of the best for potting or bedding........... I IO 900 Mont Blanc. Pure white; grand spike.... I 50 I 2 oo

\section{SINGLE PINK AND RED}

Baron van Thuyll. Fine pink; large, compact spike; early .................. s oo \$8 oo Charles Dickens. Delicate pink; decidedly one of the best; always gives satisfaction. . I 25 II 00 General Pelissier. One of the best; deep

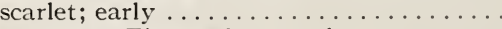

Gertrude. Fine red; very large, compact truss; excellent for bedding out, as it

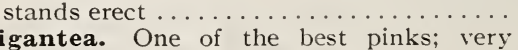

Gigantea. One of the best pinks; very
large truss; fine for bedding out ........ I o 
FIRST-SIZE SINGLE HYACINTHS, continued

SINGLE PINK AND RED, continued

Homerus. Red; very early .......... IO $_{20} \$_{\text {IO }}^{\text {IOO }}$

Lord Macaulay. Very fine bright red,

with white center; very large, compact

truss ................... I oo 9 oo

Moreno. Extra-fine pink; compact truss; large bell; found in every exhibition

collection .............. I 20 Io 00

Norma. Fine pink; one of the best for

early forcing.................. I oo 8 oo

Roi des Belges. Deep scarlet........ I oo 9 oo

Von Schiller. Red; large; extra fine... I 20 Io oo

\section{SINGLE BLUE}

Baron van Thuyll. Deep blue; very large truss; early...............

Charles Dickens. Light blue; very

large, compact truss ............. I oo 9 oo

Czar Peter. Light porcelain-blue; one of the finest.
SINGLE BLUE, continued

Grand Lilas. Fine lilac; very large, compact truss ............... SI oo So $_{0}$

Grand Maitre. Deep porcelain-blue; very large truss ............... $85 \quad 700$

King of the Blues. The finest of the deep blues

La Peyrouse. Fine light blue........ $75 \quad 600$

Lord Byron. Fine lilac-blue; large

spike ................. I 20 Io 00

Potgeiter. Light blue; fine-shaped bulb. I 20 Io

Queen of the Blues. A variety of real

merit .................... I oo 900

Regulus. Light blue; fine for bedding or forcing ............... $90 \quad 700$

\section{SINGLE YELLOW}

Ida. This is the best pure yellow for early forcing................. I 20 Io 00

La Citroniere. Bright citron-yellow.. I 20 Io 00 L'Or d'Australie. Golden yellow; fine spike ................. I 20 Io

\section{BEDDING HYACINTHS}

Mixed bulbs should never be used for house or greenhouse culture, and even for bedding purposes we recommend named bulbs, second size or separate colors.

\section{SINGLE}

Red. All shades

$\ldots \ldots \ldots+\ldots, \ldots+\ldots$

Blush-White. ...................... 50

Dark Blue. All shades ............... 350

Light Blue. All shades ............... 350
Yellow. All shades ................ $\$_{5}$ oo

All Colors Mixed . . . . . . . . \$35 per I, o, 350

\section{DOUBLE}

All Colors.............\$45 per $1,000 \ldots 5$ oo

\section{BEDDING OR FORCING SECOND-SIZE NAMED HYACINTHS}

These are of the best maturity and of good size, especially adapted for forcing or bedding. They are sure to produce large and vigorous spikes of bloom. Plant 6 to 9 inches apart and 6 inches deep.

This is equal to "First Size" of many dealers. HIGH-GRADE is shown by the fact that MY SALES FOR THIS SIZE HAVE INCREASED YEARLY FOR FORCING as well as for bedding.

\section{SINGLE RED AND PINK}

\begin{tabular}{|c|c|c|c|}
\hline & IO & IO & \\
\hline Charles Dickens...........\$ & 75 & $\$ 6$ & OO \\
\hline Gigantea $\ldots \ldots \ldots \ldots \ldots \ldots$ & 60 & 5 & OO \\
\hline Lord Macaulay ... & 65 & 5 & 50 \\
\hline Robert Steiger ........... & 60 & 5 & 50 \\
\hline Baron van Thuyll ..... & 65 & 5 & 50 \\
\hline General Pelissier . . . & 60 & 5 & oo \\
\hline Gertrude ...... & 60 & 5 & oo \\
\hline$\ldots \ldots \ldots \ldots$ & 70 & 6 & $\mathrm{OO}$ \\
\hline$\ldots \ldots \ldots \ldots \ldots$ & 60 & 5 & OO \\
\hline
\end{tabular}

\section{SINGLE WHITE}

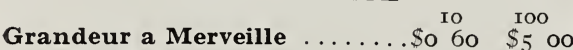

L'Innocence ............. $75 \quad 6 \quad 50$

Baroness van Thuyll ........ $656_{5} \quad 550$

La Grandesse ............ $75 \quad 650$

Madam Vanderhoop ........ $75 \quad 600$

\begin{tabular}{|c|c|c|}
\hline \multirow{2}{*}{\multicolumn{3}{|c|}{ SINGLE BLUE }} \\
\hline & & $\begin{array}{l}\text { IOO } \\
\$ 50\end{array}$ \\
\hline Czar Peter . . . . . . . & 75 & \\
\hline Iaitre & 65 & \\
\hline & 60 & \\
\hline Gr: & 75 & \\
\hline les & 60 & \\
\hline & 60 & \\
\hline Qu & 75 & 6 \\
\hline & & \\
\hline
\end{tabular}

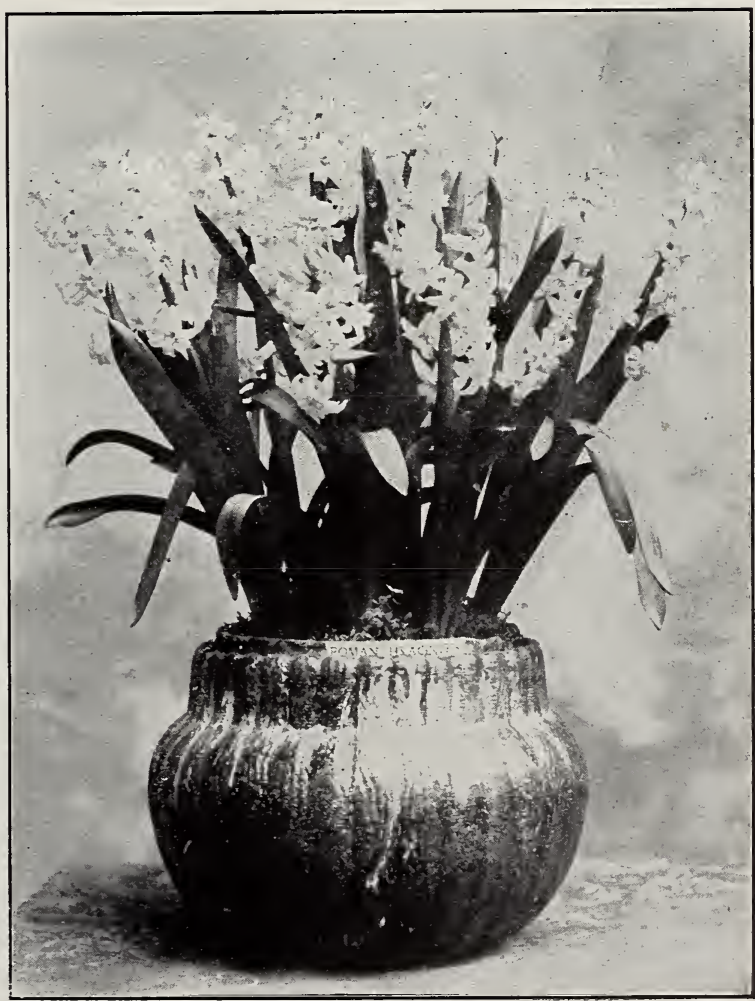

ROMAN HYACINTHS 


\section{FRENCH ROMAN HYACINTHS}

A charming class of Hyacinths, producing graceful, delicately perfumed spikes of flowers; they force readily in the house. Each bulb produces several spikes. Their treatment is the same as that of other Hyacinths. The white variety is used by the million for early bloom. Potted in September, they will flower in December. The

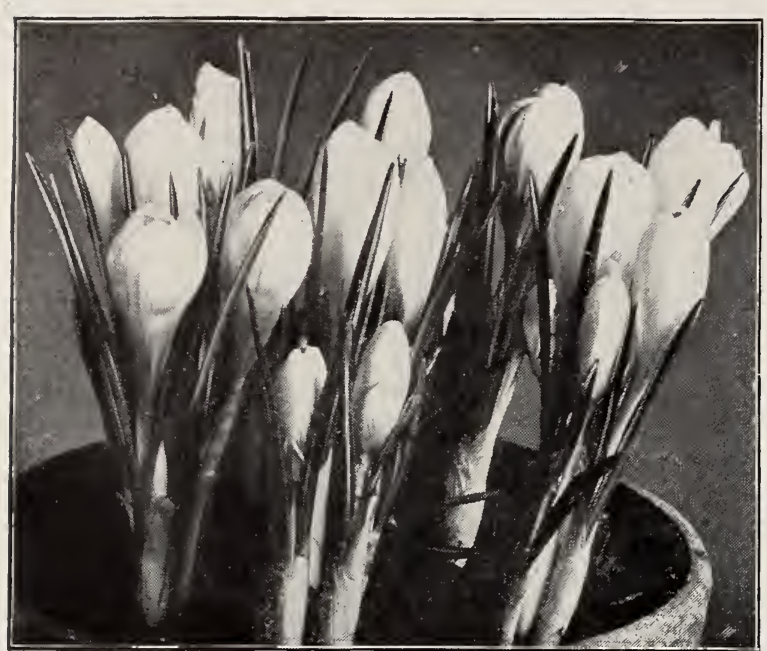

CROCUS whole success of pot culture with these, as with Dutch Hyacinths, tulips, narcissi, etc., depends upon getting roots well established in the pot at a low temperature of 40 to 50 degrees, before bringing them into a temperature of the living-

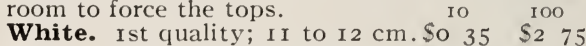
" Select; i 2 to $15 \mathrm{~cm} \ldots . . .40400$ Extra; 13 to $15 \mathrm{~cm} . . . .50 \quad 50 \quad 400$ Fancy; $15 \mathrm{~cm}$. and up.. Single Yellow .............. 60 500 Blue ............. 40 300 Light Rose $\ldots \ldots \ldots \ldots \ldots \ldots$
Dark Rose

\section{CROCUSES}

Crocuses should be more used than they are. They are entirely hardy and increase from year to year. They are the first to flower after the snowdrops, and make a magnificent show in the grass, as well as in the border. When a large number are to be planted, proceed as follows: With the spade cut the sod at right angles; turn it back on a hinge (as it were), putting in a few bulbs around the sides of the hole; turn the sod back and tread firmly. Planted with Scilla Sibirica, a fine show is produced

\section{SELECT NAMED CROCUSES}

75 cts. per $100, \$ 6$ per 1,000, except where noted

Mixed Crocuses are not, in my estimation, worth planting, hence I offer none, since a first-class named bulb will give three times as many flowers of larger size than those of a small-sized bulb generally sold in mixtures "The best is the cheapest."

\section{BLUE}

Albion. Large; dark purple; very early; extra. Baron Bruno. Magnificent dark blue; large flower. Non Plus Ultra. Blue, bordered white.

\section{WHITE}

King of the Whites. New; choice. Mont Blanc. White; very fine.

Queen Victoria. Extra.

White, Yellow, Purple, Blue and Striped, equal number of each color, selected blubs, XXX size of soris named above at $\$ 6$ per $1.000, \$ 55$ per 10.000

\section{NARCISSI (Daffodils)}

No spring flower is more charming and none more easily grown than the Daffodil. They are all grand forcers, and outof - doors they improve from year to year if let alone. Naturalized in the grass or open woods, they make a fine distant effect. They have proven successful in every position. The leaves ripen and disappear before mowing-time. "Ten years ago," says an English writer, "I planted many thousands of Narcissi in the grass, and they have thriven admirably, bloomed well and regularly, the flowers are large and handsome, and, in most cases, have not deteriorated in size." ALL LARGEST SIZE BULBS.

\section{SINGLE TRUMPET DAFFODILS}

Bicolor Grandis. A little later than the other Bicolor varieties.................. \$o $25 \$ 200$

Bicolor Empress. Very fine; large yellow, with pure white perianth $\ldots \ldots \ldots \ldots \ldots \ldots \ldots$. $\ldots \ldots$.

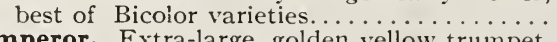

Emperor. Extra-large, golden yellow trumpet, with rich primrose perianth .................
olden Spur. Large deep yellow; one of the best in cultivation.

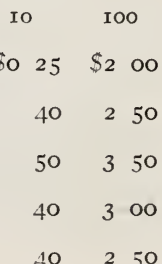

\section{YELLOW}

Mammoth Bulbs. 85 cts. per I00, $\$ 7$ per 1,000

\section{STRIPED AND VARIEGATED}

Albion. Striped; extra.

Mme. Mina. Extra large; splendid; the earliest.

Sir Walter Scott. White and violet-striped; very fine.

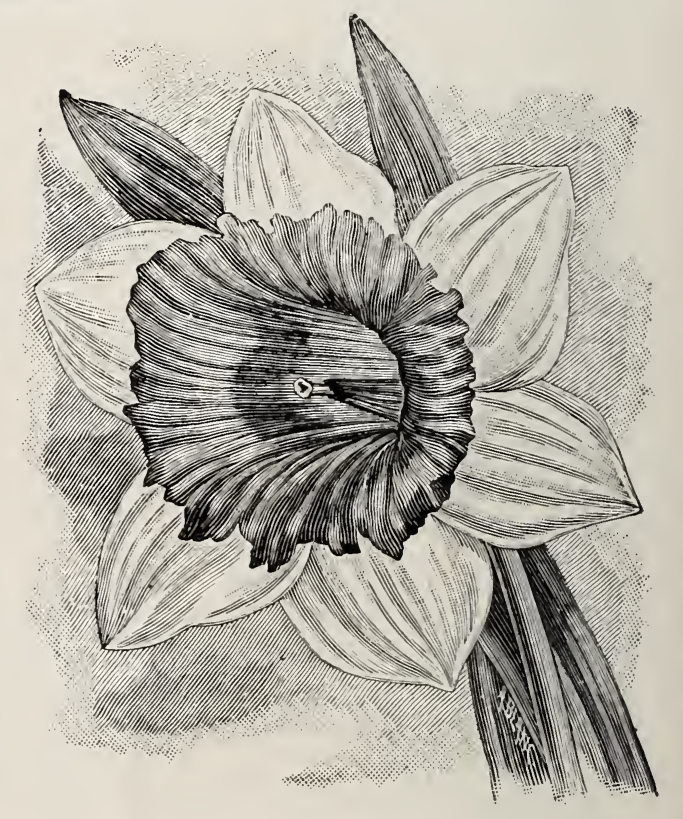


SINGLE TRUMPET DAFFODILS, continued

Henry Irving. Golden yellow trumpet, with large, wheel-shaped perianth . .

Trumpet Maximus. Golden yellow.

Trumpet Major. Golden yellow trumpet and perianth; fine for forcing early... \$I2 per I, OoO

Mrs. Langtry. Pure white; a gem for cutting

Princeps. Primrose perianth, deep yellow trumpet; early forcer

Sir Watkins. Fine for forcing and cutting

\section{DOUBLE DAFFODILS}

Alba plena odorata. Double Poet's, or Gardenia-flowered Daffodil. In sweetness and purity it rivals Gardenia blossoms. White. I5 cts. for Io, SI per Ioo, S9 per I,O0o.

Orange Phœnix. White, with orange center; extra-fine flower. 25 cts. for IO, \$1.75 per roo.

Sulphur Phonix. Pure white and sulphur; delicious odor; very fine. 40c. for Io, \$3 per Ioo.

Van Sion. Large, doul:e-nose bulbs, each of which will give two or more flowers. $30 \mathrm{cts}$. for IO, $\$ 2.50$ per IOo, $\$ 24$ per I, Ooo

Van Sion. Extra-large, XXX, double-nose mother bulbs, which will produce from three to five flowers. $40 \mathrm{cts}$. for Io, $\$ 3.50$ per IOO, \$28 per I, OoO.

Van Sion. Single nose; fancy: selected. 25 cts. for IO, \$I.55 per IOO, \$I 2 per I.OOO.

The Van Sion I offer are unexcelled mammoth bulbs

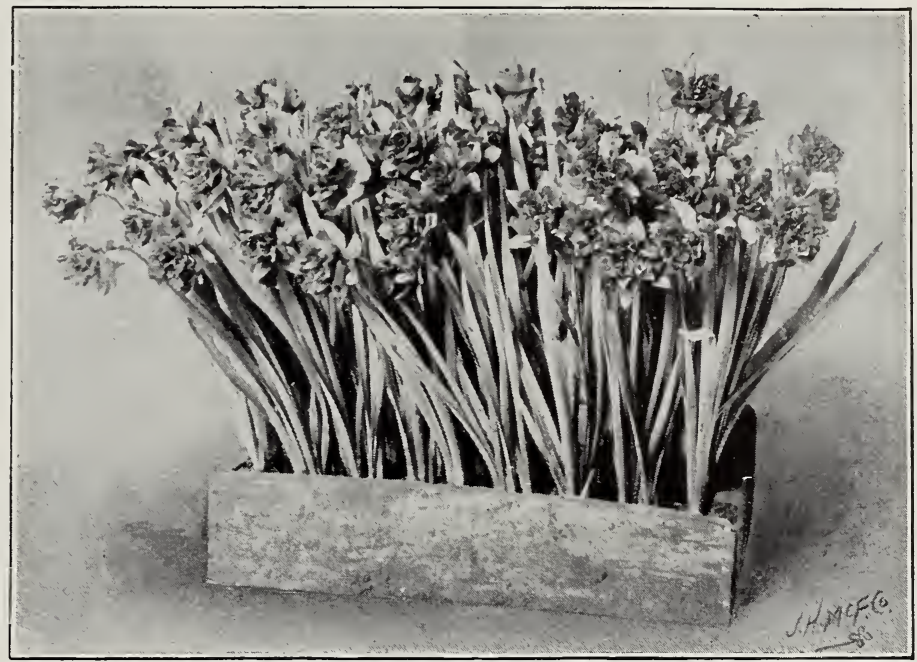

VAN SION DAFFODILS

\section{SWEET-SCENTED SMALL-FLOWERED SINGLE NARCISSI}

Jonquilla simplex. Sweet-scented Jonquil. Yellow. 20 cts. for Io, 90 cts. per Ioo.

Jonquilla Stella. White, with yellow cup. I 5 cts. for ro, $90 \mathrm{cts}$. per 100.

Jonquilla Campernelle. I 5 cts. for IO, \$I per I00, \$7 per I,000.

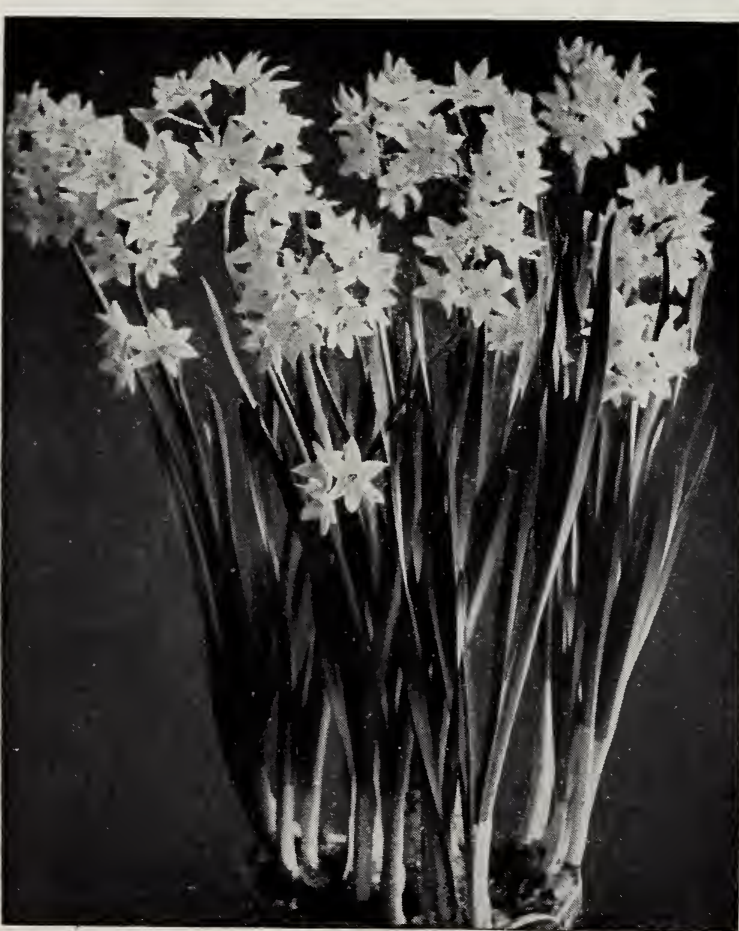

PAPER WHITE NARCISSI

Jonquilla rugulosus. 20 cts. for Io, $\$ 1.25$ per IOO, \$IO per I,000.

Poeticus (Pheasant's Eye). Pure white, red crown; very sweet; cannot be forced. Io cts. for Io, 60 cts. per I0o, $\$ 4.50$ per I,000.

Poeticus ornatus. Pure white, sweet-scented, cup tinged rosy scarlet; very fine for forcing; much earlier than the old variety. I5 cts. for IO, \$I.IO per IOO, \$8 per I,000.

SPECIAL LOW OFFER IN MIXTURES 50 Trumpet Narcissi, in 10 sorts, on page 6 , $\$ 1.50$.

100 Trumpet Narcissi, in 10 sorts, on page 6, \$2.50.

100 Double Daffodils and Jonquils, many sorts, $\$ 1 ; \$ 7.50$ per 1,000 .

100 Single Daffodils and Jonquils, many sorts, $\$ 1 ; \$ 8$ per 1,000 .

GIANT PAPER WHITE NARCISSUS. Easily grown in earth or water, and better than the Chinese Sacred Lily; deliciously scented. Their tall spikes of bloom, with many florets to each spike, may be had by Christmes if planted the last of September. Mammoth bulbs, 30 cts. per doz., \$2 per Ioo, \$I 5 per I,OOO. I, OOO bulbs in case.

PAPER WHITE, GRANDIFLORA. Fancy About I,250 bulbs in case. \$1.40 per IOO, $\$$ I 2 per case.

CHINESE SACRED LILY. This fairy flower of the Chinese may be easily grown in an open dish half filled with pebbles and water. Their highly perfumed flowers appear in about two months from time of planting. Mammoth bulbs, Io cts. each, \$I per doz.; original basket containing 30 bulbs, $\$ 1.75$; per mat of r $20, \$ 6.50$. 


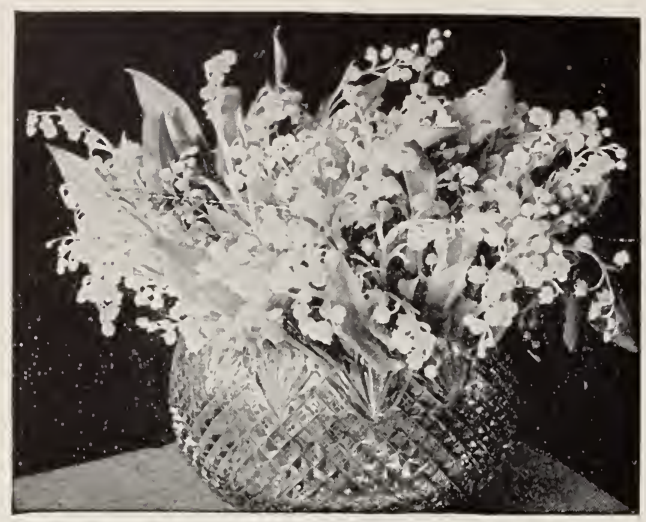

LILY-OF-THE-VALLEY

\section{FORCING LILIES}

\section{BERMUDA EASTER LILIES}

Lilium multiflorum. Japan-grown- Io Ioo 6 to 8 inches in cir.............\$ 60 o $\$ 4$ oo 7 to 9 inches in cir............ I oo 7 oo

9 to ro inches in cir........... I 25 Io 00

Lilium longiflorum. Japan-grown-

6 to 8 inches in cir............ $65 \quad 5$ oo

7 to 9 inches in cir............. I oo 7 oo

9 to ro inches in cir........... I 25 Io 00

Lilium Harrisii- Each ro Ioo

5 to 7 inches in cir.....\$ \$o Io \$o $75 \$ 6$ oo

6 to 7 inches in cir......... I5 I oo 7 oo

7 to 9 inches in cir...... 20 I 25 IO 00

9 to II inches in cir...... $25 \quad 2 \quad 25 \quad 2000$

\section{GARDEN LILIES}

Candidum (Madonna, or St. Joseph's Lily). THICKPETALED variety. Coming into bloom with the roses and blue larkspur, what a pageant they form! This Lily is easy of culture, quick to increase, and thrives in almost any soil and position. Like other Lilies, they should not be disturbed. Plant in early September for best results. Choice bulbs, \$I per doz., \$7 per Ioo; mammoth size, $\$$ I.25 per doz., $\$ 8$ per Ioo.

Japanese Lilies may be planted in spring or fall with excellent results. They are especially appropriate for garden or border of old-fashioned flowers, including the Tiger Lily. The following varieties are choice and easy of culture:

Auratum. 8 to 9 inches, \$I per doz.; 9 to II inches, \$I.50 per doz.

Speciosum album. 8 to 9 inches, $\$$ I.50 per doz.; 9 to I I inches, $\$ 2.50$ per doz.

Speciosum rubrum. 8 to 9 inches, $\$$ I.25 per doz.; 9 to II inches, $\$ 2$ per doz.

Speciosum Melpomene. 8 to 9 inches, $\$$ I.2O per doz.; 9 to II inches, $\$ 2$ per doz.

Tigrinum splendens. Choice bulbs, \$I per doz., \$7 per Ioo.

Twenty bulbs of each of these five sorts, largest size, 100 in all, $\$ 12$; next size, $\$ 9$

\section{LILY-OF-THE-VALLEY}

(Ready in November)

I cannot too highly recommend my Lily-of-theValley. If more of my customers were aware of the abundant bloom the clumps give (with no care except to set them out) I am sure sales would be greatly increased.

XXX Grade. Berlin Pips. For Christmas forcing. \$2 per I0o, \$I6 per I,00o.

XXX Grade. Berlin Pips. A high grade for late forcing. \$2 per Ioo, \$I 4 per I,000.

Strong clumps for outdoor planting, containing I 2 to I5 crowns, \$3 per doz., \$2O per Ioo.

\section{CALLAS}

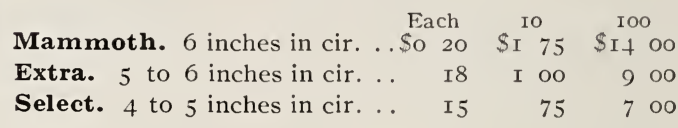

\section{ASTILBE (Ready in November)}

Astilboides floribunda.......... IO $_{\text {IO }}$ OO $\$ 6$ I00

Japonica. The old favorite ......... I oo 6 oo Japonica, Gladstone. The finest of all. I 50 Io 00 Japonica compacta multiflora ...... I oo 6 oo

\section{FREESIA}

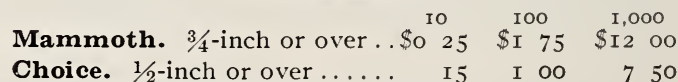

Purity. This magnificent new Freesia with its large, snowwhite flowers, produced on long stems, has proved itself a worthy acquisition. This can be used where white carnations can be used for decorative purposes ...........

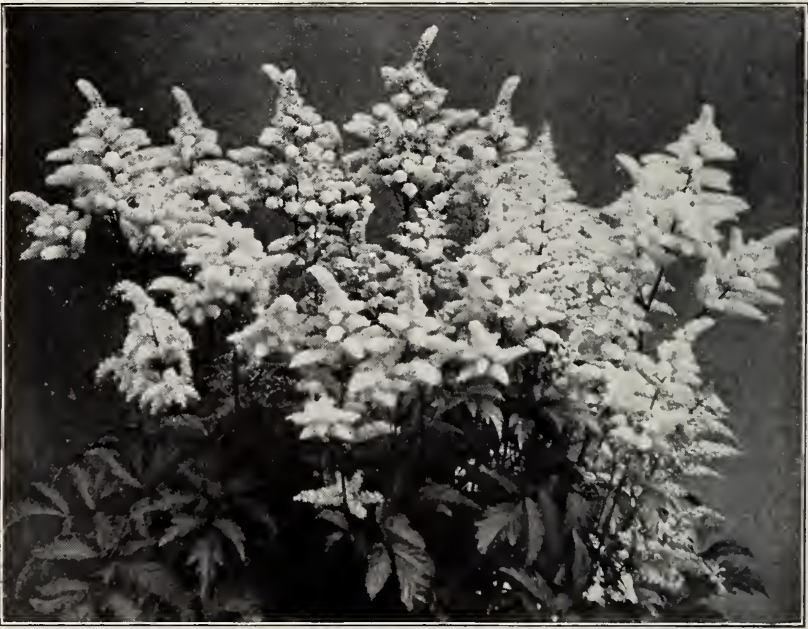

ASTILLE JAPONICA GLADSTONE

\section{THE TESTIMONY OF A SATISFIED CUSTOMER}

MR. S. G, HARR1S, Tarrytown, N. Y.

Dear Sir:-It is a pleasure. I n assure you, to state that all of the bulbs, peonies and roses which I have purchased from you from time to time have proven most satisfactory. I know that the bulbs which you have furnished me have been, beyond any question, the finest of their kind I have ever seen. Raising a great many of these and being very fond of flowers, I feel as if I had a right to say they certainly have no superior on the market anywhere. It has been a pleasure for me from time to time to tell my friends of my most satisfactory dealings with you, and $I$ assure you it has always been gratifying for me to be able to turn a great many people in your direction.

Wishing you the success which I feel you deserve, I remain,

Yours very truly, 


\section{Superior Roses for Discriminating Buyers}

We have arranged to supply to our customers heavy two-year-old plants that will produce grand plants the first season. We import thousands of Roses yearly from Dickson \& Sons, the famous growers in Ireland. Our stock includes only first-class varieties and first-class plants.

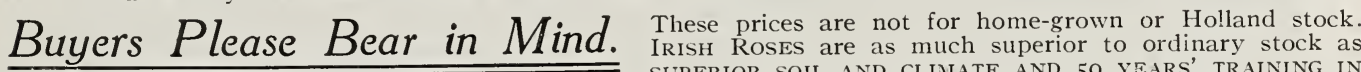
$=$ SUPERIOR SOIL AND CLIMATE AND 5O YEARS' TRAINING IN ROSE-GROIVING CAN PRODUCE. To produce such stock, strong one-year plants are set in spring and grown two years in the field; quite different from plants started in the greenhouse in winter, planted out in spring and sold the following spring for two-year-old plants. The fact that we send these IRISH Roses to nearly all the large estates AT LENOX AND NEwPORT, where the gardeners are known to be as well up in their profession as any in the country, is proof positive of the quality of our stock.

\section{"The Proof of the Pudding."}

Three years since a customer asked us to send him I50 Roses, our selection. He has since ordered over 300 , and two of his nearest neighbors have ordered over 50o. This kind of advertising pays well, since its only cost is select stock, well packed and shipped at the proper time, together with cultural directions when desired, which is no more than every customer has a right to expect.

By permission, we submit the following letter from one of America's greatest sculptors NEW YoRK, November 13, 1905.

S. G, HaRris, Esq. Tarrytown, N. Y.

Dear Sir: The Roses which you sent me last spring gave such beautiful flowers from June until late in the fall that I wish to have you duplicate the order, if you can do so, next spring. Yours very truly,

Daniel Chester French.

Our new Catalogue describes nearly 200 of the best Roses. Ask for it before buying

\section{NEW ROSES}

Mrs. David Jardine. (H. T.) A gloricharming Rose, and one that is of immense importance to this section. It possesses vigorous and erect growth, together with marvelously free-flowering habit. The blooms, which are produced on every shoot, are of very large size and perfect form, beautiful in its several stages of development. The color is a delightful shade of bright rosy pink, shading in the outer petals to salmon-pink; quite distinct from any existing variety.. In this Rose we have produced a flower

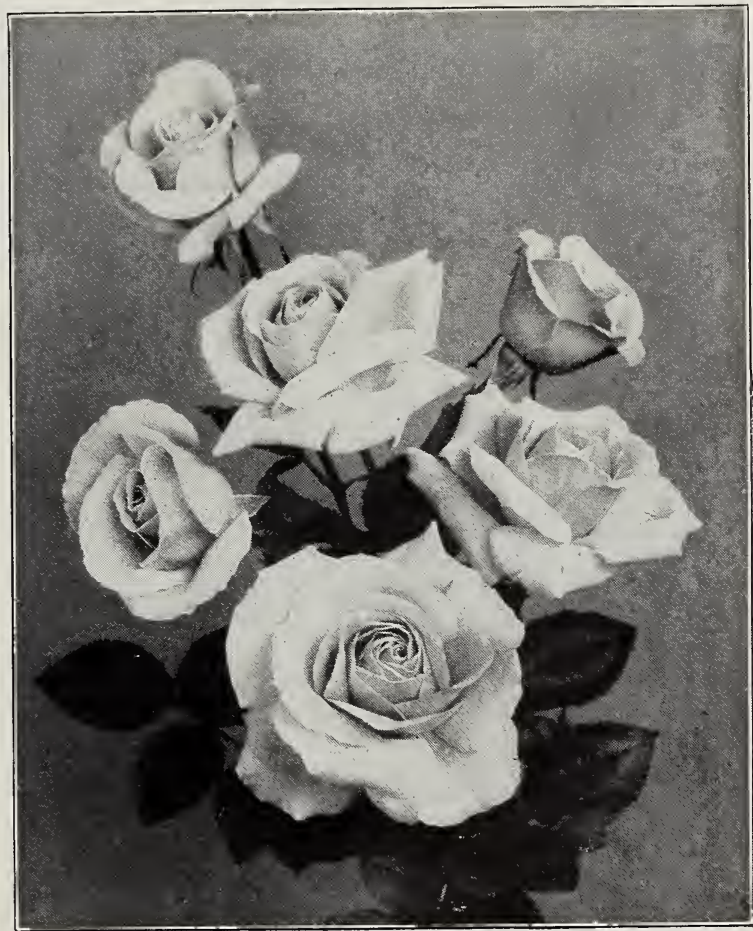

MRS. DAVID JARDINE possessing all the chasteness and floriferousness

of a Tea, combined with the erect and vigorous growth of a Hybrid Perpetual. It will eventually supersede the Catherine Mermet type. It has been inspected growing and flowering by the Committee of the New York Florists' Club, who gave their Diploma of Superiority, awarding it the HIGHEST NUMBER OF POINTS EVER GIVEN TO A NEW Rose since the formation of the Society., Price, $\$ 2$.

Harry Kirk. (Tea). Absolutely unique. A splendid Rose, of most robust growth, with free-branching habit, Harry Kirk. flowering freely and continuously. The blooms are large, full, with large, smooth petals of great substance; the form is perfect; the buds are long and elegant; color deep sulphur-yellow, passing to a lighter shade at edges of petals. A splendid Rose, much the best of its color. A marvelous acquisition. A warded Gold Medal, N. R. S. Doctor Huey, of Philadelphia, writes: "HARRY KIRK is a great and glorious Rose. I had five different periods of bloom last summer. I had several blooms that opened $4 \frac{1}{2}$ inches in diameter. As the inner row of petals is incurved, even when fully opened, it does not present a flat appearance. Petals are of great substance and the flower is quite fragrant." Price, \$I.50 each.

The plants are grown by Rose-growers of over fifty years' experience in the north of Ireland, where soil and climate conspire to produce plants of great vigor, strong roots and well-ripened wood.

THE PLANTS ARE VERY LOW-BUDDED, so that in planting the bud or graft is easily placed 2 or 3 inches below the surface of the ground (as it should be) without the necessity of too deep planting of the roots.

THE PLANTS ARE KEPT PERFECTLY DORMANT from the time they are dug until they reach our customers. On arrival late in November, we place them in deep trenches and cover with earth until shipping time. By this method there is no drying of the roots, as there is where stored in buildings.

Our method of packing insures arrival in perfect condition.

SPECIAL OFFER OF NEW ROSES. Our enthusiasm for the following grand new varieties has induced us to prepare a large stock in order that every customer may have some of them. All extra-heavy, two-year-old plants.

Alice Grahame. Ivory-white, tinted salmon.

Antoine Rivoire. Rose-flesh; superb.

Baby Rambler. Best scarlet bedder

Bessie Brown. One of the finest Roses ever raised.

Etoile de France. Velvety crimson

Frau Karl Druschki. Best white Hybrid Perpetual.
Gruss an Teplitz. Best crimson bedder.

Killarney. Best light pink

Madame Abel Chatenay. Best rosy carmine.

Madame Ravary. Best orange-yellow.

Mildred Grant. White, tinted pink. The grandest variety ever raised. 
ROSES, continued

In addition to the Roses named below, we offer over one hundred and fifty choice varieties including Frau Karl Druschki, Mrs. Crawford, Ulrich Brunner, Ben Cant, Baron Rothschild, etc. Two-year selected plants, $35 \mathrm{cts}$. each, $\$ 350$ per doz., $\$ 25$ per 100 . Write for General Catalogue.

In addition to our regular two-year-old stock, we offer transplanted three-year-old plants of many of the Climbing Roses, Rugosas, and miscellaneous sorts, of which the price is 50 cts. each, $\$ 5$ per doz.

$\begin{array}{lccl} & \text { Roses at } \mathbf{4 0} \text { cts. each, } \$ 4 \text { per doz., } \$ 30 \text { per } & 100 \\ \text { Antoine Rivoire } & \text { Corallina } & \text { Gustave Nabonnand } & \text { Madame Cadeau Ramey } \\ \text { Ards Pillar } & \text { Countess of Gosford } & \text { K. A. Victoria } & \text { Madame Ravary } \\ \text { Balduin } & \text { Climbing K. A. Victoria } & \text { Killarney } & \text { Maman Cochet } \\ \text { Beryl } & \text { Climbing Belle Siebrect } & \text { Lady Battersea } & \text { Mildred Grant } \\ \text { Bessie Brown } & \text { Enchantress } & \text { Liberty } & \text { Mrs. Robert Garrett } \\ \text { Blanc Double de Coubert } & \text { Ferdinand Batel } & \text { Madame Joseph Combet } & \text { Mrs. Theo. Roosevelt } \\ \text { Carmine Pillar } & \text { Franz Deegan } & \text { Madame Pernet Ducher } & \text { White Maman Cochet } \\ \text { Caroline Testout } & \text { Frau Peter Lambert } & & \end{array}$

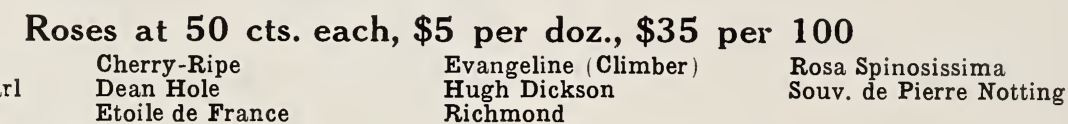

\section{Alice Grahame Climbing Frau Karl Dean Hole Etoile de France \\ Evangeline (Climber) \\ Richmond \\ Rosa Spinosissima \\ Twenty-four Choice Ever-blooming Roses-Hybrid Teas} Souv. de Pierre Notting

We are pleased to offer the following thoroughly tested varieties of Roses, which bloom from June to November. Many of them are well-known favorites. The newer varieties have proved most satisfactory in many parts of the country during the past two or three years.

$\begin{array}{lllll}\text { Alice Grahame } & \text { Caroline Testout } & \text { Gruss an Teplitz } & \text { La France } & \text { Madame Ravary } \\ \text { Antoine Rivoire } & \text { Franz Deegan } & \text { Helen Gould (Balduin) } & \text { Liberty } & \text { Mrs. Robert Garrett } \\ \text { Ard's Pillar } & \text { Frau Peter Lambert } & \text { Kaiserin Augusta Victoria } & \text { Mme. Abel Chatenay Souv. du Pres. Carnot } \\ \text { Bessie Brown } & \text { Gladys Harkness } & \text { Killarney } & \text { Mildred Grant } & \text { Viscountess Folkestone } \\ \text { Captain Christy } & \text { Grace Darling } & \text { Lady Battersea } & \text { Malmaison (Bourbon) }\end{array}$

\section{The Best Twelve Hardy Garden Roses}

The following varieties, all things considered, are fully equal to any twelve of their class (H.P.). Some rosarians would doubtless prefer other varieties for some of them. We have placed the names of a few in parentheses, which may be substituted if the purchaser prefers. For description of these Roses and others, including Sweetbriers, Rugosas, Climbers, etc., see our General Catalogue.

Baroness Rothschild (Luizet)

Clio (Prince Camille de Rohan)

Earl of Dufferin (Louis Van Houtte)

Margaret Dickson (Magna Charta)

\author{
Francois Michelon (Rodocanachi) \\ Frau Karl Druschki (St. Amande) \\ Helen Keller (Jacqueminot)
}

Fisher Holmes (Jean Liabaud)
Marshall P. Wilder (Tom Wood)

Mrs. R. G. S. Crawford (Paul Neyron) Mrs. John Laing (Queen of Queens) Ulrich Brunner (Soleil d'Or)

\section{STANDARD ROSES}

We offer a grand collection of Rose Trees on both Rugosa and Canina stock in the best varieties of Hybrid Teas and Hybrid Perpetuals. XX size, 3 to 5 plants, \$I .25 each; 6 or more plants, $\$$ I each. X size, 3 to 5 plants, \$I each; 6 or more, 75 cts. each.

We also have a splendid stock of Standard Crimson Rambler, Baby Rambler and Dorothy Perkins on Rugosa stock at the following prices, namely: Crimson Rambler, 2 -yr., 75 cts.; 3 -yr., $\$ 2 ; 4-y r$., $\$ 3$. DorothyPerkins, 2-yr., \$I.50; 3-yr., \$2.50. Baby Rambler, 2-yr., \$I; 3-yr., \$I.50.

In addition to the varieties mentioned in our General Catalogue, we offer about fifty of the best varieties.

\section{ALPINE AND ROCK GARDEN}

Those having our General Catalogue will note the many varieties of plants suitable for planting in rock-gardens. Not every estate has a suitable place for such a garden, but many places with very little care and expense could be made to suit the growth of these flowers to perfection, reproducing the pleasing effects often found by travelers in the Swiss mountains. Between now and planting time in September, we shall be pleased to assist those who wish to lay out gardens of this kind.

\section{GRASS SEED}

Tarrytown Lawn Grass Seed. $25 \mathrm{cts}$. per lb., 50 lbs. or more at $20 \mathrm{cts}$. per $1 \mathrm{~b}$.

Special Mixture of Lawn-Restoring Seed. \$I.25 per pk., \$5 per bus. of 24 lbs.

Shady Lawn Mixture. \$I.75 per pk., \$6 per bus.

Special Grasses for dry ground, wet ground, sterile soil, etc. $\$+$ to $\$ 5.50$ per bus.

\section{FERTILIZERS}

Canada Hard-Wood Ashes. \$2.50 for 200 lbs., \$I 8 per ton. Car-lots prices on application.

Pulver.zed Sheep Manure. "Wizard Brand." \$2 for Ioo lbs., \$30 per ton.

Ground Bone. Coarse, for shrubs and trees, $\$ 4$ for 200 lbs., $\$ 35$ per ton; medium, for grass, $\$ 3.50$ for 2001 bs., $\$ 30$ per ton; bone flour, for pots and beds, $\$+.50$ for 200 lbs., $\$+0$ per ton. 


\section{HARDY PERENNIALS}

\section{DELPHINIUMS}

We would call attention to our large stock and great variety of Delphiniums (Larkspur). Our enthusiasm for the Erskine Park Hybrids has led us to prepare an immense stock. We offer prices on page I6

\section{IRIS}

Among all hardy perennials there is no family which has a greater variety of choice flowers more easily grown than the different groups of Iris. Our General Catalogue gives a long list of those which have been well tested and proven to be the best grown.

\section{Spanish Iris (Xiphoides)}

These choice early Irises give more flowers for the money than any other Iris. By covering the bed with glass in the beginning of April, the flowers may be cut in May. Without glass, they bloom in early June.

Baron von Humboldt. Fine blue.......... \$o 50

Belle Chinoise. Very fine yellow ........ 75

British Queen. Pure white; extra......... 75

Chrysolora. One of the best pure yellows ..... 50

Count of Nassau. Best dark blue; sweet-scented 90

Emperor of the West. Bronze; large flower... 75

La Tendresse. Cream-white. ........... $66_{5}$

Louise. Lilac-blue; very large; extra fine ..... 75

Leander. Deep yellow; very large flower;

scented $\ldots \ldots \ldots \ldots \ldots \ldots \ldots \ldots \ldots \ldots$

\section{English Iris (Anglica)}

These beautiful flowers are second only to the Japanese in beauty, and some think they are even more greaceful, not being so heavy. The markings are exquisite. They come in bloom after the German Iris and before the Japanese. WE OFFER TEN GRAND SORTS AT 5O CTS. PER DOZ., \$2.5O PER IOO, AND MONT BLANC, THE FINEST WHITE, AT 5O CTS. PER DOZ., \$2.5O PER IOO; VERY FINE MIXED, \$I.5O PER IOO.

Those interested in German or Japanese Iris should send for list of choicest imported varieties

\section{PHLOX}

The author of "A Woman's Hardy Garden" says: "There is no flower more beautiful, more easily cultivated, or giving so much bloom as the Phlox. I certainly could never have a garden without it." Plant in September and early October for best results. Plant also in April."

Following the Iris and Peonies in time of bloom, but in no way behind them in popularity, are the Hardy Perennial Phloxes. We have finally succeeded in getting up a good stock of some of the varieties which are always short at planting time. We have weeded out all the magentas and purples and believe that our list is as select as that offered by any firm. The season having been favorable, our stock will be especially fine for September and October planting. Blooming size, I 5 cts. each, \$I.25 per doz., \$8 per ioo. Large clumps, XX, 20 cts. each, \$2 per doz., \$I 2 per Ioo. See choice varieties in our General Catalogue.

Amazon. Large flower; pure white. Fine.

Belvidere. Salmon-pink. A choice sort.

Bridesmaid. White, with large crimson center.

Beranger. White, suffused with pink; rosy lilac eye.

Caran d'Ache. Bright carmine-rose; distinct.

Coquelicot. Fine, rich scarlet, with deep carmine eye.

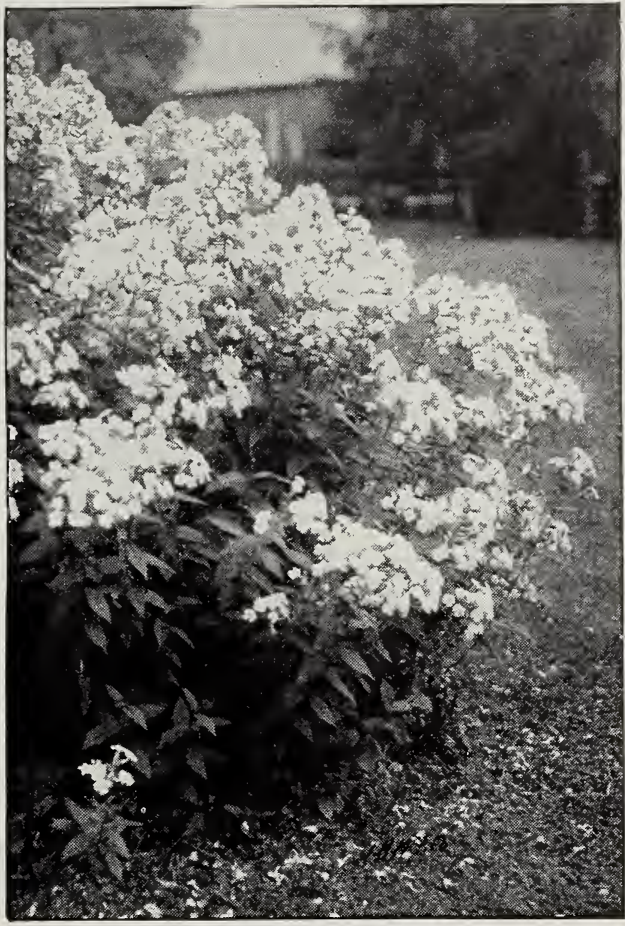

PERENNIAL PHLOX

Cross of Honor. Each petal lilac-color, with a white margin; beautiful.

Flambeau. Large flower; bright orange-red, dari: center; fine.

Henry Murger. White, with carmine eye. The best of its color.

La Vague. Large; rosy pink, with red eye; choice.

Lothair. Large; rosy salmon, with crimson eye.

Matador. Large flower; bright orange-red. Distinct and fine.

Professor Schlieman. Salmon-rose, with carmine eye.

Pantheon. Deep salmon-rose; very fine.

Peachblow. Delicate pink, with white markings.

Pearl. Pure white.

Purity. Snow-white.

Queen. Pure white.

Pecheur d'Islande. Soft salmon-scarlet, with a white center.

R. P. Struthers. Bright rosy red; crimson eye.

Sunshine. Deep salmon-pink; dark eye.

William Robinson. Flowers very large; pale salmon, with rose center. Fine.

Miss Lingard. We offer a fine stock of this new, everblooming variety. This Phlox blooms in May, fully six weeks eariier than the other sorts, and continues in bloom three months; a grand white variety, which should be in every collection; is not so tall a grower as Queen. Although the demand for this variety excels that of all other whites, we have put the price very low. Height 2 to 3 feet.

Phlox subulata (Moss Pink). Rose-pink. subulata alba. White.

Prices of all Perennials not priced on page 16, as follows: $15 \mathrm{cts}$. each, $\$ 1.50$ per doz. 


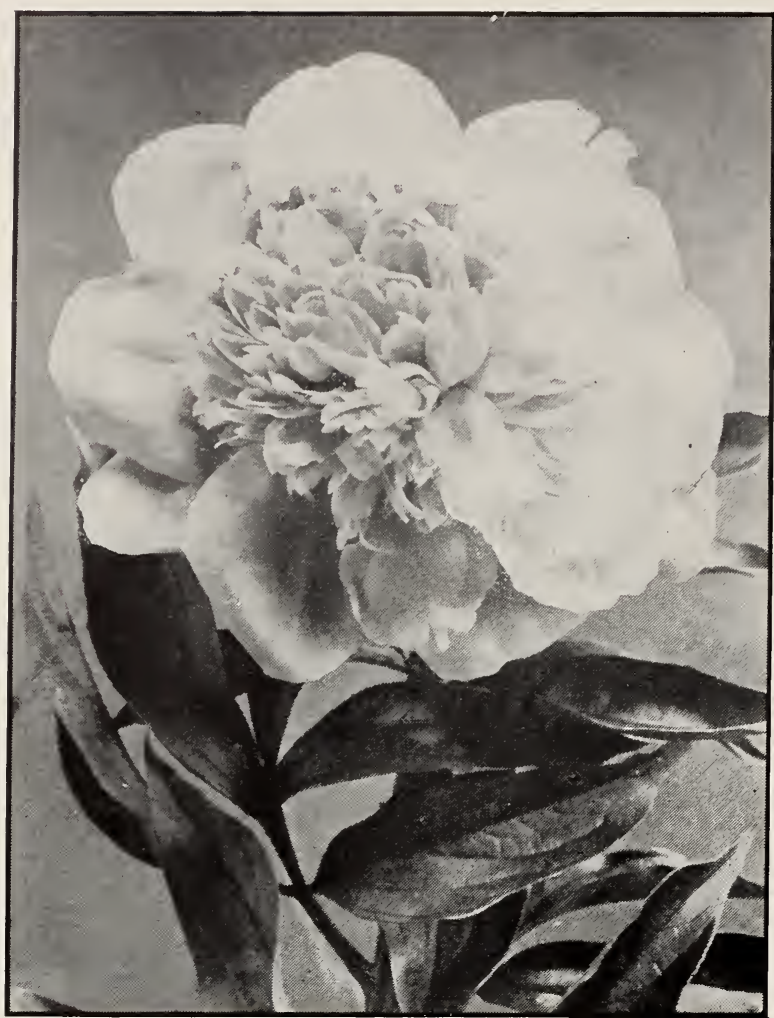

MODESTE, GUERIN PEONY

\section{PEONIES}

No flower exceeds the Peonies in popularity, and none is more easily grown. They are not attacked by insects or disease, and are perfectly hardy, requiring no covering in the severest weather. They thrive in all kinds of soil and flourish in a rich, deep loam. They demand much moisture at blooming time, and if grown in partial shade the blooms will, therefore, last longer and be equally fine in other respects. Plant eyes 2 inches below the surface and pack the earth firmly about the roots.

Although they may be planted in spring or late fall, best results are obtained if planted in September, as the plant becomes sufficiently established to mature the bloom the following June.

\section{A Word About Varieties}

Our stock was originally purchased of four of the most reputable growers known to the trade, and by careful handling in planting, digging and shipping our customers may rely on varieties true to name.

The best customer on our books was secured years ago by an order for \$10 worth of $\mathrm{Peo}$ nies, our selection.

We have discarded many varieties which we consider unworthy of cultivation, retaining other varieties much better of practically the same color. There have been originated nearly 3,000 varieties of Peonies, many of which have long since been discarded by most of the growers as unworthy of cultivation. There are still many varieties offered in some localities which within two or three years will be a thing of the past. Such beautiful varieties have been brought out during the past few years, since the revival of the herbaceous plants, that it seems useless to continue a large list of old varieties not half as good, either from lack of distinct and beautiful color, size, vigor or other good qualities. It was the concensus of opinion at the American Peony Society held at Cornell University in June last that roo to I5o varieties would cover all that would be worth growing, including early, medium and late varieties of the different colors from white, yellow, pink, rose, scarlet and purple. We believe we have a list which will need but little revision, simply a few more additions of the sorts recently introduced.

\section{Preparation of the Soil}

To perfect so many large blooms as a good clump of Peonies will set, the soil should be well prepared so that plenty of nourishment as well as moisture may be had at blooming time. No fertilizer is better than well-rotted cow manure, which should be used in liberal quantities, but placed far enough below the roots so that the rootlets will not be affected by it until they have well started to grow. If the subsoil is of a good loamy texture, the excavation of 2 feet with a layer of 6 inches of well-rotted cow manure at the bottom, well spaded in, will be sufficient. If however, the subsoil is of the nature of hardpan, it should be removed entirely and alternate layers of old sods and manure put in its place. Heavy clay should be lightened by the aid of sand, leaf mold and manure, mixing it thoroughly by overturning several times. Plants should be set at least 3 feet apart so that they will have ample room for development.

A good way to utilize the ground the first season or two is to plant a row of phlox between the rows of Peonies. Should there be an extreme drought in April or May, a thorough drenching of the beds once or twice a week would well repay in extra bloom. As phlox are fond of the same treatment, these plants thrive well together, the latter giving a succession of bloom for two months after the Peonies are over.

\section{A Word About Prices}

We have endeavored to make our prices so attractive as tu bring many orders for our large stock. This does not mean, however, that we shall be overcome by the temptation to cut the roots into such small fragments that they will not bloom the first season. Every one of our plants will bloom next June and July if planted in early autumn. Grown on ground especially adapted to Peonies, and in a very favorable season, our plants have developed strong roots and plump eyes. We offer three sizes, viz.

Ist size, 3 to 5 eyes; $\mathrm{XX}$ size, 6 to 8 eyes;

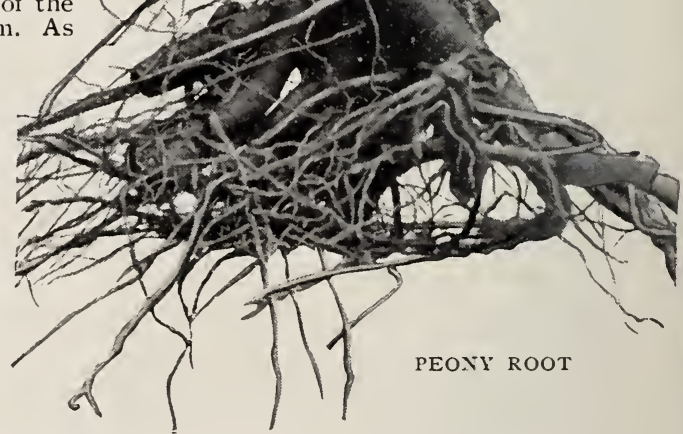

3 of a kind af dozen rate. Discount of 5 per cent on orders from $\$ 20$ to $\$ 50$; 10 per cent on orders for $\$ 50$ or more 


\section{ONE HUNDRED SUPERB PEONIES}

The quality may be seen from the fact that we supply many of the most noted places. We can guarantee ours true to name. There is no department of floriculture in which the customer is so much at the mercy of the careless or unscrupulous dealers as in Peonies. One dealer cuts the roots so small that the blooms amount to little before the third year; and another (himself honest, perhaps) has imported from one of those growers who labels one plant correctly, and the balance of the Ioo, more or less, of the same variety, may be almost any color. Plant in autumn, and one year from date your plants will be worth double their cost.

\section{SINGLE JAPANESE}

They measure 6 to 7 inches across. Twelve varieties of the very finest in cultivation, including all the delicate shades from pure white to purple. 50 cts. each, $\$ 5$ per doz.

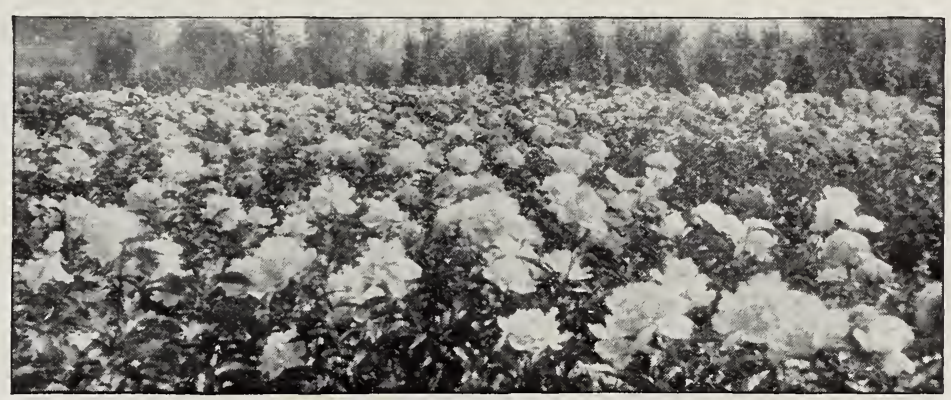

ONE OF OUR FIELDS OF PEONIES

\section{DOUBLE CHINESE}

Hardy as an oak, thriving in any rich soil and with the least possible care. The choice double varieties named below should be in every garden. Heavy clumps which will bloom the first season.

Alba sulphurea (Calot, I860); syn. Mont Blanc, of which see description.

Artemise. (Calot, I86o.) Rose of several tints; good form. Ist size ........\$o 35 \$3 50

$\mathrm{XX}$ size $\ldots \ldots \ldots \ldots \ldots \ldots \ldots \ldots$ 6о $6 \ldots \ldots$

Ambroise Verschaffelt. (Parmentier, I85o.) Purplish crimson; very full, fragrant; one of the finest. Ist size..

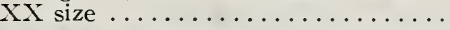

Auguste Lemonier. (Calot, I865.) Velvety red; large, full, beautiful. Ist size ................

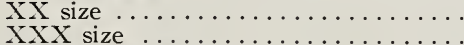

Atrosanguinea. (Calot, I85o.) Deep blood-red; metallic luster; early and

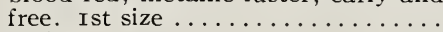

XX size

Baroness Schroeder. Flesh, changing to white; vigorous and free bloomer; very scarce. We can supply only one plant of this variety in an order.

Berlioz. (Crousse, I886.) Late; large, full, globular; bright currant-red. Ist size $\ldots \ldots \ldots \ldots \ldots \ldots \ldots \ldots \ldots \ldots \ldots \ldots \ldots \ldots \ldots$ I
$\mathrm{XX}^{50}$

Carnea elegans. (Calot, I860.) Clear fleshy yellow, glossy reflex. Ist size.

Charles Binder. (Guerin, I86o.) Violetred; fragrant; good. Ist size .....

XX size

Charles Gosselin. (Guerin, I855.) Salmon-color, center light yellow. Ist

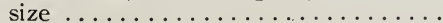

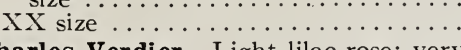

Charles Verdier. Light lilac-rose; very large and of perfect form; a superb variety; late. Ist size ..........

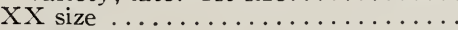

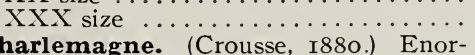

Charlemagne. (Crousse, I88o.) Enormous flowers, very double, imbri-
cated; flesh-white, center tinted lilac cated; flesh-white, center tinted lilac
and chamois; very fine; late. Ist size

$\mathrm{XX}$ size $\ldots \ldots \ldots \ldots \ldots \ldots \ldots \ldots \ldots$ I

XXX size ................ I 50

Claire Dubois. (Crousse, I886.) Light rosy pink; center full; large flower; very fine. Ist size............. I 50

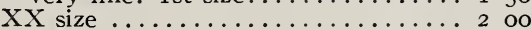

Doz.
Couronne d'Or. (Calot, I873.) White, with yellow reflection, center petals bordered red; extra; late. Ist size. .\$I oo \$Io oo $\mathrm{XX}$ size ................. I 50 I 5 oo XXX size $\ldots \ldots \ldots \ldots \ldots \ldots \ldots 2$ oo

Daniel d'Albert. Deep rose, shaded purple; large, globular flower. Ist

size $\ldots \ldots \ldots \ldots \ldots \ldots \ldots \ldots$ 6o 6 oo

Delicatissima......... I oo Io oo cate fine pink; large, full and sweet. Ist size ................ 6o 6 oo

$\mathrm{XX}$ size ............... I oo Io oo

De Candolie. (Crousse, i88o.) Currantred, tinged amaranth; distinct color; best of its shade; very large and double; fine. Ist size ......... 6o 6 oo

XX size ................ I oo ro oo

Delachii. (Delache, I854.) Dark purplish crimson, shaded violet; late; fine. Ist size

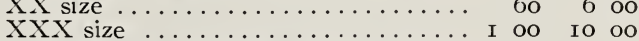

Dr. Bretonneau. (Verdier, 1854.) Rosy violet; large and fine; fragrant. Ist size $\ldots \ldots \ldots \ldots \ldots \ldots \ldots \ldots \ldots$ so 5 oo

XX size .................. $75 \quad 750$

Duchesse de Nemours. (Calot, I856.) Sulphur-white; fragrant; good shape; late; extra. Ist size .......... 60 o 6 oo

$\mathrm{XX}$ size $\ldots \ldots \ldots \ldots \ldots \ldots \ldots \ldots \ldots \ldots$ I о о

XXX size ................. I 50 I5

Duke of Wellington. (Calot, I859.) Large, well-formed, sulphur-white bloom; habit ideal; stems very firm and long; strong grower; fragrant. .

Ist size ................. $40 \quad 4$ oo

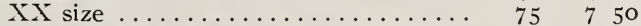

Edulis, or Fragrans. (Sir John Banks, I805.) Violet-rose, all of one color;

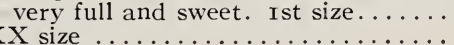

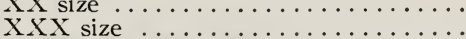

Eugene Verdier. (Calot, I864.) Salmonpink, changing to clear pink, nearly white; very fine. Ist size ........ I 25

Felix Crousse. (Crousse, I88 I .) Bright red, distinct color; fine bomb-shape; large, massive; no stamens; late. Ist

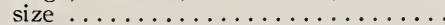

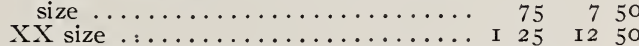

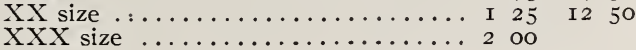




\section{SUPERB PEONIES, continued}

Festiva maxima. (Millez, I85I.) For Each fifty years the standard of perfection in Peonies. Pure paper-white, with carmine-flaked tips to a few center petals. Immense; very fragrant, early and free. Ist size ......... \$o 50 o $\$ 5$ oo $\mathrm{XX}$ size

XXX size

Festiva. (Donkaclair, I838.) Very much like Festiva maxima, but dwarfer and later. Ist size.

XX size ........................... Apparently identical with Delicatissima (sec page I3).

Fulgida. (Parmentier, I854.) Crimson; profuse-flowering; extra fine. Ist size XX size

XXX size

General Bertrand. Rosy violet, center salmon; large and showy...........

Gloire de Boskoop. Pure white, choice varicty. Ist size ............ I oo

XX size

Gloire de Chas. Gombault. Large bloom, extra full deep fleshy pink collar, center petals clear fleshy salmon-color, shaded apricot; tuft of broad petals, pink striated with carmine; multicolor variety; color of a great freshness. Late midseason. XX size

Gloire de Chenon ceaux. (Mechin,I88o) Very large, full blooms; bright satinpink, lightly shaded with white; late bloomer. Ist size .............

XX size ........ (Rosenfield.) Very striking variety, producing large, tricolored blooms, the guard petals being blush-pink, with a distinct blushwhite collar and blush center; a few of the center petals tipped and striped light crimson, the general effect of the flower being creamy pink; delicate fragrance. Ist size

$\mathrm{XX}$ size

XXX size

Grandiflora carnea plena. (Lemon, I824.) Very large; outside petals delicate blush; center fringed, yellowish; sweet and fine. Ist size....

XX size.

Henri Demay. (Calot, i866.) Violetpurple; very large and full; fragrant; late. Ist size

XX size

Humei. (Guerin, I856.) Purplish rose; very full and double; very large and showy, and one of the latest in bloom. As much as three weeks later than the earliest of the Peonies. Ist size. .

XX size

Insignis. (Guerin, I85o.) Carmine-rose; fine form, fragrant; good. Ist size.

$$
\mathrm{XX} \text { size }
$$

Jeanne d'Arc. (Calot, I858.) Outside petals rose-colored, inside strawcolored, with crimson spots. Ist size

XX size

Jussieu. (Guerin, I850.) Deep blackpurple;

Lady Curzon. White guard, with cream center. Award of merit at Royal Horticultural Society. Ist size.... XX size

L a Rosi ere. (Calot, I888.) Large flower; double, well-shaped; globular. Petals broad; center pale yellow, yellowish white border. This variety resembles a tea rose. Ist size ......

XY size
Doz.

850

I 25 I 250

404 oo

25250

$50 \quad 500$

I 00 I0 00

$50 \quad 500$ I 00

I 50

(1)

50

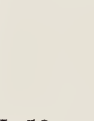

$90 \quad 900$
Latipetala. Outside petals flesh-color, Each center ones yellowish white. Very large and fine. Ist size.........\$ 60 o $\$ 6$ oo XX size........ I oo 10 oo

La Tulipe. (Calot, I872.) White, center rose; exterior bright carmine, center dark carmine striped; beautiful in bud and bloom. Ist size ........ $60 \quad 600$

$\mathrm{XX}$ size ................ I oo 10 oo

Livingstone. (Crousse, I879.) Very solid pale pink with no guard, and very free. A late bloomer and the massive buds develop slowly. Winner of first prize for pink at the Chicago Peony Exhibition, June, I905. Ist size.... I 25

$\mathrm{XX}$ size ....................... 2 oo

Louise Renault. (Crousse, I88I.) Very double, compact bloom; petals are broad; large, slate-colored-pink; late. Ist size

Louis Van Houtte. (Delache, I8 84 .) Dark crimson; very compact; fragrant and late. Ist size........ $35 \quad 350$

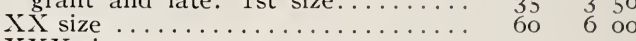

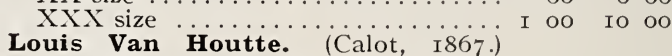
Bright purple-cherry; large, globular and full; fragrant; superb. Ist size. $35 \quad 350$

$\mathrm{XX}$ size ................ 6o 6 oo

XXX size ............... I oo Io oo

Mme. Bollet. (Calot, I867.) Very large bloom: fleshy pink, white reflex, striped carmine; late bloomer. Ist size .................. 6o 6 oo

$\mathrm{XX}$ size $\ldots \ldots \ldots \ldots \ldots \ldots \ldots \ldots \ldots \ldots \ldots$ I 00 10

Mme. Chaumy. (Calot, I864.) Soft pink, shaded bright rose, clearer on border of petals. Ist size....... 6o 6 oo

$\mathrm{XX}$ size ............ I oo Io 00

Mme. Crousse. (Calot, I866.) White, tinted pink, center carmine bordered; very fragrant. Ist size.....

$\mathrm{XX}$ size $\ldots \ldots \ldots \ldots \ldots \ldots \ldots \ldots \ldots$ I 50

Mme. de Galhau. (Crousse, I892.) Large imbricated bloom, very soft, glossy, shaded flesh or transparent salmon; late midseason. Ist size... I oo

$\mathrm{XX}$ size $\ldots \ldots \ldots \ldots \ldots \ldots \ldots$ I 50

Mme. de Vatry. (Guerin, I863.) Large bloom of perfect shape, guard petals clear flesh, center sulphur-white, with carmine stripes. Late midseason. Ist size $\ldots \ldots \ldots \ldots \ldots \ldots \ldots \ldots$ I 60

Mme. de Verneville. (Crousse, I885.) Enormous well-shaped flower, pure white; first-class variety; delightfully fragrant. Ist size ..............

Mme. Emile Galle. A good clear pink, lighter shade toward the center. Ist

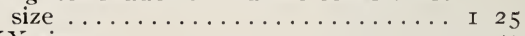

XX size .............. I 50

Mme. Ducel. (Mechin, I88o.) Midseason. Perfectly formed globular bloom, color bright silvery pink, tinted and marked with salmon and silvery reflex. Fine for cutting. This is offered by some growers under the name of Modele de Perfection. Ist

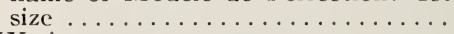

XX size . . . . . . . . . . . . . . . Fuli,
Ime. cup-shaped bloom; color flesh-pink, with silvery reflex center, petal bordered with carmine. Late variety.

Ist size ................ 6o 6 oo

XX size ................ I oo Io oo

Mme. Geissler. (Crousse, I880.) Silvery rose, shaded crimson; large and full; fine form; one of the best. Ist size .................. 5o 5 oo

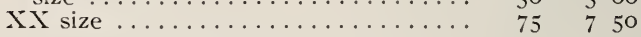


SUPERB PEONIES, continued

Mme. Lebon. (Calot, I885.) Very Each Doz. large; bright cherry, some petals white; fragrant, good. Ist size....\$ \$o $35 \quad \$ 3 \quad 50$ XX size

Mme. Victor Verdier. (Calot, I866.) Crimson-rose, with light violet; very large and full; late. Ist size ........

$$
\text { XX size }
$$

Marie. White, washed chamois; very late variety. Ist size.......... I oo $\mathrm{XX}$ size ................... I 50

Marie Lemoine. (Calot, I869.) Large; flesh white; fine dwarf habit. Ist size I oo

$\mathrm{XX}$ size ................... I 50

Meissonier. (Crousse, I886.) Brilliant purple-amaranth; broad petals; crimson center; enormous, full flower.

Ist size $\ldots \ldots \ldots \ldots \ldots \ldots \ldots \ldots \ldots$

XX size

Mlle. Marie Calot. (Calot, I872.) $\mathrm{Me}$ dium size; shape of Centifolia rose; color finest flesh-pink, with glossy background lighted with silvery tints Extra fine. Ist size............ I oo

XX size ................. I 75

Mlle. Rousseau. (Crousse, I886.) Sulphur-white, salmon center; large, full flower; very fine shape. Only one in an order. Ist size.......... I 50

$\mathrm{XX}$ size ................ 250

Modele de Perfection. (Crousse, I875.) Large, cup-shaped bloom, fresh pink, marbled bright rose, with silvery

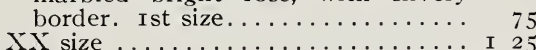

Modeste. (Guerin, I845.) Deep rose; bright and showy; very large, distinct and fine-shaped; fragrant: superb variety. Ist size.........

XX size......................

Monsieur Boucharlataine. (Calot,
I868.) I868.) Bright rosy lilac; large and fragrant; midseason. Ist size......

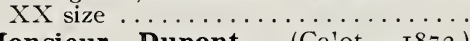

Monsieur Dupont. (Calot, I872.) White, tinged yellow, carmine-bordered; late. Ist size $\ldots \ldots \ldots \ldots \ldots$ I oo Io oo

XX size ................. I 50 I 5 oo

Monsieur Jules Elie, (Calot, I873.) Clear flesh-pink; massive shape and very large. Free bloomer. Ist size.. I oo ro oo

XX size ................ 2 oo

Monsieur Krelage. Broad petals; bright currant-red, amaranth cen-

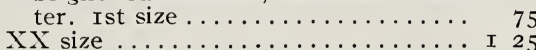

Mont Blanc (Lemoine, I899); syn., Sulphurea. Fine, large, early, fragrant; white, with lemon center, giving the general appearance of a light sulphur-yellow; habit strong and vigorous; fragrance pronounced; excellent shipper. Ist size ........

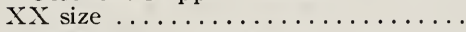

Nobilissima. (Milliez, I858.) Very large, bright deep pink, silvery border; full bloomer. Ist size.......

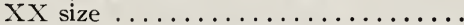

Ornament des Massifs. (Crousse, I893.) Large blooms, very full; fine glossy pinkish flesh-color; late variety. Ist size ..............

Papilionacea. Outside petals rose, center yellow, changing to white. Ist

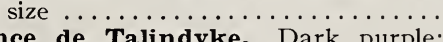

Prince de Talindyke. Dark purple; large, distinct. Ist size .........

$\mathrm{XX}$ size $\ldots \ldots \ldots \ldots \ldots \ldots \ldots \ldots \ldots$

Prince Imperial. (Calot, I879.) Large bloom, very brilliant purplish scarlet. Ist size ..................
$40 \quad 400$ 75

Princess Beatrice. Pink guard petals, Each center yellow. Ist size. ..... \$I OO

Richardson's Dorchester. (I870). Late; dwarf grower, free bloomer; compact, erect habit; delicate salmon flesh. Fine for all purposes. Ist size. $\mathrm{XX}$ size

$60 \$ 6$ oo

Richardson's rubra superba. (Richardson, I87I.) Brilliant deep crimson; the latest of all Peonies to bloom; fragrant; apt to blast in Massachusetts. Ist size $\ldots \ldots \ldots \ldots \ldots \ldots \ldots$ 5o 5 oo

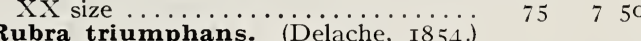
Dark purplish crimson; petals large: very sweet; semi-double. Ist size.

$\mathrm{XX}$ size

Sarah Bernhardt. (Dessert, I895.) Large blooms, guard petals of a pretty pink, salmoned center; beautiful variety; good habit. The earliest of Chinese Peonies. Ist size I oo

$\mathrm{XX}$ size ................ I 50

Solfaterre. (Calot, I86r.) Sulphur-yellow; an extra good sort. Ist size... I oo

$\mathrm{XX}$ size .................... I 50

Souv. de L'Exp. Universelle. (Calot, I867.) Very large imbricated flower of perfect shape, rich, clear cherry, very brilliant with silvery reflex; blossoms in clusters. Ist size.....

Souv. du Dr. Brettoneau. (Dessert, I880.) Large blooms in clusters bright cherry-red, lightly shaded with clear amaranth; brilliant coloring; very showy. Ist size.

Triomphe de l'Exposition de Lilie. (Calot, I865.) Delicate rose; very massive; dwarf habit; fine. Ist size.

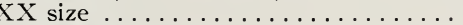

XXX size …… (Milliez, I85o.) Violet-rose, shaded with lilac; a fine color; beautiful. Ist size . . . . . . . .

$\mathrm{XX}$ size $\ldots \ldots \ldots \ldots \ldots \ldots \ldots \ldots$ 5o 5 oo

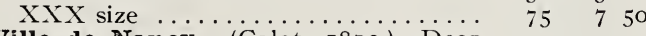

Ville de Nancy. (Calot, I872.) Deep brilliant crimson; late. Ist size..... $75 \quad 750$ $\mathrm{XX}$ size $\ldots \ldots \ldots \ldots \ldots \ldots \ldots \ldots$ I 25 I2

XXX size ............... I 75

Violacea. (Verdier, I856.) Deep purpleviolet; very large and full. Ist size. .

XX size

Viscomtesse Belleval. (Guerin, I852.) Blush, center creamy white; beautifully fringed; fragrant. Ist size...

40400

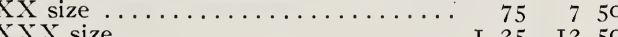

XXX size $\ldots \ldots \ldots \ldots \ldots \ldots \ldots \ldots$ I 25 I 250 positively identified as named varieties. Ist size $\ldots \ldots \ldots \ldots \ldots \ldots$ I 5 I 50

\section{PAEONIA OFFINALIS}

Alba plena. Double white, tinged red. Ist size $\ldots \ldots \ldots \ldots \ldots \ldots \ldots \ldots \ldots$ Rosea. Double crimson, changing to rose; fragrant. Ist size. ............

Rosea superba. Shining satiry rose; magnificent flower. Ist size........

Rubra. Double crimson, of large size;
fragrant; the old-fashioned red Peony Ist size $\ldots \ldots \ldots \ldots \ldots \ldots \ldots \ldots$

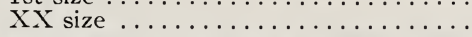

Tenuifolia. Single; dark crimson; very rich fern-like foliage; flowers distinct; earliest flowering. Ist size..

Tenuifolia fl. pl. Double, fennel-leaved flowers of a bright scarlet-crimson, and quite double and globular; rare and fine. Ist size...............

$\mathrm{XX}$ size.................. I 25 Tree Peonies will be priced on application 


\section{HARDY PERENNIALS}

A Word About Prices. We offer hundreds of the best varieties of Hardy Perennials, including Asters, Chrysanthemums, Columbines, Ferns, Hollyhocks, Larkspurs, Lilies, etc., at $15 \mathrm{cts}$. each, $\$ \mathrm{r} .50$ per doz. Only the few varieties named below differing from this price.

We have greatly increased our facilities for supplying the old-fashioned flowers, including improved new hybrids and many varieties especially adapted to the Alpine and rock-garden.

Prices of all hardy perenniels listed in our catalogue, not named on this page, will be furnished at $15 \mathrm{cts}$. each, $\$ 1.50$ per doz.

Six at dozen rates, fifty at hundred rates, provided not less than three of a kind are ordered. No charge for boxing and packing orders amounting to $\$ 5$ or more.

\begin{tabular}{|c|c|c|c|c|c|}
\hline Acanthus $\ldots \ldots \ldots \ldots \ldots \ldots \ldots$. ${ }^{\text {Each } 25}$ & $\begin{array}{l}\text { Per doz. } \\
5 \$ 250\end{array}$ & ICO & Hemerocallis aurantiaca major... Each 50 & $\begin{array}{l}\text { Per doz. } \\
\$ 5 \text { oo }\end{array}$ & 100 \\
\hline Achillea, The Pearl............... & & $\$ 600$ & Florham ...................... 50 & 500 & \\
\hline Aconitum..................... 25 & 250 & & Hibiscus.$\ldots \ldots \ldots \ldots \ldots \ldots \ldots \ldots \ldots \ldots \ldots \ldots$ & I 25 & \\
\hline Actaea $\ldots \ldots \ldots \ldots \ldots \ldots \ldots \ldots \ldots \ldots, 25$ & 250 & & Iris, Alpine..................... 25 & 250 & \\
\hline Adonis vernalis................ 25 & & & Cristata..................... I5 & I 25 & \\
\hline Alyssum saxatile compactum fl. pl.. 25 & 250 & & 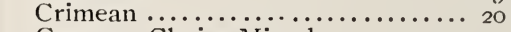 & 200 & \\
\hline Anthericum..$\ldots \ldots \ldots \ldots \ldots \ldots$ Ic & I OO & & German, Choice Mixed............ & I oO & $\$ 600$ \\
\hline $\mathbf{s}, \ldots \ldots \ldots \ldots \ldots \ldots \ldots \ldots+20$ & 200 & & German, Named................ I5 & I 50 & \\
\hline randiflorum............... & 250 & & Japanese, named................. 25 & 250 & \\
\hline mnis............... Ic & 75 & 500 & Aese, Extra Choice Mixed..... I5 & I 50 & IO \\
\hline la gigantea Mœrheimi..... 25 & 250 & & са.................. Iо & I 00 & \\
\hline $\begin{array}{l}\text { Pyramidalis } \ldots \ldots \ldots \ldots \ldots \ldots \cdots \\
\text { Chrysanthemums }\end{array}$ & 250 & & Lychnis Chalcedonica fl. pl......... 25 & 250 & \\
\hline $\begin{array}{l}\text { Chrysanthemums } \ldots \ldots \ldots \ldots \ldots \ldots \ldots \\
\text { Set of } 25 \text { varieties, } \$ 2 \ldots \text { IC }\end{array}$ & & & Lysimachia................... & 25 & \\
\hline $\begin{aligned} \text { Set of } 25 \text { varieties, } \$ 2 . . & \text { Ic } \\
\ldots \ldots \ldots \ldots \ldots \ldots \ldots \ldots \ldots \ldots & 25\end{aligned}$ & I 00 & 800 & $\begin{array}{l}\text { Monarda didyma } \ldots \ldots \ldots \ldots \ldots \ldots \ldots \\
\text { Montbretias }\end{array}$ & I 25 & \\
\hline Cimicifuga simplex.................. & $\begin{array}{ll}2 & 50 \\
5 & 00\end{array}$ & I5 00 & 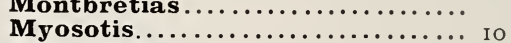 & $\begin{array}{r}30 \\
\text { I }\end{array}$ & \\
\hline ....................... 25 & 250 & & OEnothera...$\ldots \ldots \ldots \ldots \ldots \ldots \ldots$ & I 25 & \\
\hline$\ldots \ldots \ldots \ldots \ldots \ldots \ldots \ldots \ldots$ I0 & I OO & 600 & Omphalodes.................... 20 & 200 & \\
\hline Delphinium belladonna........... 25 & 250 & & Peonies. See pages 12 to 15 for de- & & \\
\hline $\begin{array}{l}\text { Colestinum........................ } \\
\text { Erskine Park Hybrids. Superb. }\end{array}$ & 200 & 1200 & $\begin{array}{l}\text { scription and prices. We offer } \\
\text { about } 80 \text { choice varieties. }\end{array}$ & & \\
\hline 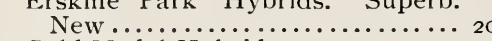 & 200 & & $\begin{array}{l}\text { about } 80 \text { choice } \\
\text { Phlox, Miss Lingar }\end{array}$ & 200 & \\
\hline Gold Medal Hybrids........... 20 & 200 & & ed. Blooming size........ I 5 & I 25 & \\
\hline , alpines, etc..... Io & I OO & 800 & $y, \ldots \ldots \ldots \ldots \ldots \ldots, 20$ & 200 & 1200 \\
\hline orts.......... 25 & 250 & & $\operatorname{ria} \ldots \ldots \ldots \ldots \ldots \ldots \ldots \ldots \ldots \ldots$ & 250 & \\
\hline$\ldots \ldots \ldots \ldots \ldots \ldots \ldots \ldots \ldots \ldots$ I5 $_{5}$ & I 25 & 800 & $\ldots \ldots \ldots \ldots \ldots \ldots \ldots \ldots$ Io & I 00 & \\
\hline$\ldots \ldots \ldots \ldots \ldots \ldots \ldots \ldots, 25$ & 250 & I5 00 & $\ldots \ldots \ldots \ldots \ldots \ldots \ldots \ldots, 25$ & 250 & I5 \\
\hline$\cdots \cdots \cdots \cdots \cdots$ & 200 & & Scutellaria..................... 25 & 50 & \\
\hline . $\ldots \ldots \ldots \ldots \ldots$ & 250 & & $\ldots \ldots \ldots \ldots \ldots \ldots \ldots \ldots \ldots \ldots, 10$ & I OO & \\
\hline ...... & 250 & & schafta.................. 25 & 250 & \\
\hline$\ldots 25$ & 250 & & $\ldots \ldots \ldots \ldots \ldots \ldots \ldots \ldots$ I5 & I 25 & \\
\hline$\ldots \ldots \ldots \ldots \ldots \ldots$ IC & I OO & & thium robustum.......... 25 & 250 & \\
\hline$\ldots \ldots \ldots \ldots \ldots \ldots \ldots \ldots$ I5 $_{5}$ & I 50 & IO 00 & Willian (Dianthus Barbatus). Io & I 00 & 0 \\
\hline 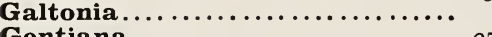 & 40 & 25 & 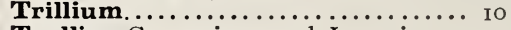 & I 00 & \\
\hline ‥ 25 & 250 & & id Japonicus.. 25 & 250 & \\
\hline & I 00 & & ica longitolia subsessilis...... 25 & 250 & \\
\hline ........... 25 & 250 & & 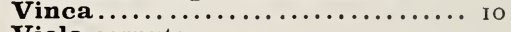 & I 00 & \\
\hline $\begin{array}{lll}\ldots \ldots \ldots \ldots \ldots & 15 \\
\ldots \ldots \ldots \ldots \ldots & 25\end{array}$ & I 25 & & $\cdots \cdots \cdots \cdots$ & 50 & \\
\hline$\because \ldots \ldots \ldots \ldots \ldots \ldots 2$ & 250 & & Yucca filamentosa. 5-year-old plants. 25 & 250 & 15 \\
\hline Helleborus & 30 & & Ordinary size. 3 -year-old plants ... 20 & I 75 & \\
\hline
\end{tabular}

\section{ORNAMENTAL DEPARTMENT}

\section{DECIDUOUS TREES}

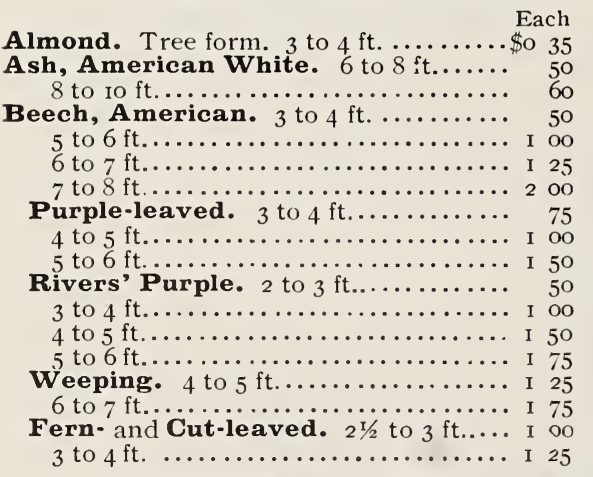

Each Per 10

Birch, Cut-leaved Weeping. 6 to $8 \mathrm{ft}$...\$I 25 \$10 00 8 to ro ft......................... I 75 i 75 oo

Pyramidal. 5 to $6 \mathrm{ft} . \ldots \ldots \ldots \ldots \ldots$ I 50 i 200

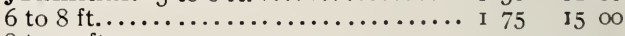

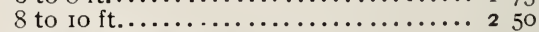

Young's Weeping. 6 to $8 \mathrm{ft} . \ldots \ldots \ldots 250$

Paper, or Canoe. 8 to ro $\mathrm{ft} . . . \ldots \ldots \ldots$ I 25

$\begin{array}{lll}5 & \text { oo } & \text { Buttonwood. See Plane. } \\ 7 & 50 & \text { Catalpa Bungei. Top-worked. } 6 \text { to } 8 \mathrm{ft} \text {. }\end{array}$

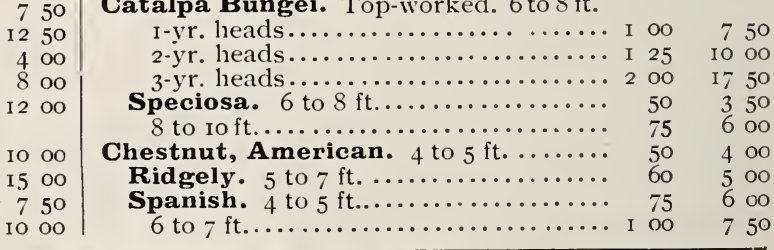


DECIDUOUS TREES, con. Each Crab Apple, Chinese Double Rose.

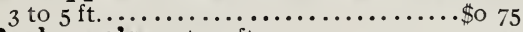

Parkman's. 3 to $4 \mathrm{ft} . . . \ldots \ldots \ldots \ldots$....... I OO

Cypress, Deciduous. 4 to $5 \mathrm{ft} . \ldots \ldots \ldots$. I oo 3 to 4 ft.......................... 60

Cytisus Laburnum. 5 to $6 \mathrm{ft} . . . \ldots \ldots$....
Dogwood, White - flowering (Cornus florida). 4 to $5 \mathrm{ft} . \ldots \ldots \ldots \ldots \ldots \ldots \ldots$. 60

5 to $6 \mathrm{ft} . \ldots \ldots \ldots \ldots \ldots \ldots \ldots \ldots \ldots \ldots \ldots \ldots$ I oo

Red-flowering. 4 to $5 \mathrm{ft} . \ldots \ldots \ldots \ldots$. I 25 5 to $6 \mathrm{ft} . \ldots \ldots \ldots \ldots \ldots \ldots \ldots \ldots \ldots \ldots \ldots \ldots$
Weeping. 3 to $4 \mathrm{ft} \ldots \ldots \ldots \ldots \ldots \ldots \ldots$

Elm, American. 6 to $8 \mathrm{ft} \ldots \ldots \ldots \ldots \ldots \ldots$. 60

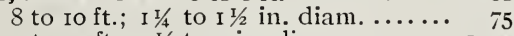
Io to $12 \mathrm{ft} . ; \mathrm{I} 1 / 2$ to 2 in. diam......... I 25 I2 to I4 ft.; 2 to 3 in. diam........... I 75

Fringe, White. 3 to $4 \mathrm{ft} \ldots \ldots \ldots \ldots \ldots$. 50 Purple. 3 to $4 \mathrm{ft} . . . \ldots \ldots \ldots \ldots \ldots \ldots \ldots$. 50

Horse-Chestnut, Double White-

5 to $6 \mathrm{ft} . \ldots \ldots \ldots \ldots \ldots \ldots \ldots \ldots \ldots \ldots \ldots$ I 25 6 to $8 \mathrm{ft} . \ldots \ldots \ldots \ldots \ldots \ldots \ldots \ldots \ldots \ldots \ldots \ldots$ I 50

Red-flowering. 5 to $6 \mathrm{ft} \ldots \ldots \ldots \ldots \ldots$ I 50

Common White. 5 to $6 \mathrm{ft} \ldots \ldots \ldots \ldots \ldots, 75$

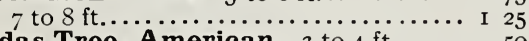

Judas Tree, American. 3 to $4 \mathrm{ft} \ldots \ldots \ldots$ 50

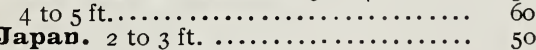

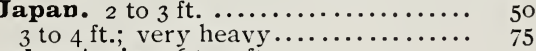

Koelreuteria. 6 to $7 \mathrm{ft} \ldots \ldots \ldots \ldots \ldots \ldots$ I 00 7 to $8 \mathrm{ft} . \ldots \ldots \ldots \ldots \ldots \ldots \ldots \ldots \ldots \ldots \ldots \ldots \ldots \ldots \ldots$ I 25

Locust (Black). Prices on application.

Larch, European. 3 to $4 \mathrm{ft} \ldots \ldots \ldots \ldots .6$..... 60 4 to $5 \mathrm{ft} . \ldots \ldots \ldots \ldots \ldots \ldots \ldots \ldots \ldots \ldots \ldots$ I 0

Linden, American-

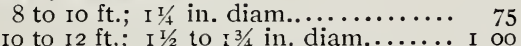

European. 8 to Io ft.; $\mathrm{I}^{1 / 4} \mathrm{in}$. diam.... 75 Io to $12 \mathrm{ft} . ;$ I $3 / 4$ in. diam. ............ I 25 I2 to I4 ft.; $21 / 4$ in. diam............. 250

Weeping. 6 to $8 \mathrm{ft} . ;$ 2-yr. heads........ I 25 8 to Io ft.; 3 -yr. heads............... I 75

Maple, Norway. 6 to $8 \mathrm{ft} . \ldots \ldots \ldots \ldots \ldots$. 75 8 to Io $\mathrm{ft}$; $\mathrm{I} 1 / 4$ to $\mathrm{I}^{1 / 2} \mathrm{in}$. diam....... I oo Io to I2 ft.; I $1 / 2$ in. diam............ I 50 I2 to $\mathrm{I} 5 \mathrm{ft}$.; $\mathrm{I} 3 / 4$ in. diam ; superb trees. 2 oo Worle's Golden-leaved. 4 to $6 \mathrm{ft}$.... I oo 6 to $8 \mathrm{ft} . \ldots \ldots \ldots \ldots \ldots \ldots \ldots \ldots$ I 50

Reitenbach's. Purple foliage. 6 to $8 \mathrm{ft}$. I 50

Schwedler's Purple-leaved Norway. 6 to $8 \mathrm{ft} . \ldots \ldots \ldots \ldots \ldots \ldots \ldots$ I 25

8 to Io $\mathrm{ft} . \ldots \ldots \ldots \ldots \ldots \ldots \ldots \ldots \ldots \ldots$ I 75

Sugar. 8 to ro ft.................... 75 Heavy, ro to $12 \mathrm{ft} . \ldots \ldots \ldots \ldots \ldots \ldots$ I 25

Wier's Cut-leaved. 8 to ro ft.......... 75 Io to I2 $\mathrm{ft} . . \ldots \ldots \ldots \ldots \ldots \ldots \ldots \ldots \ldots$ I oo I 2 to $14 \mathrm{ft}$. ; caliper, 2 to 3 in.......... I 50

Maple, Japanese-

Polymorphum. 2 to $2 \frac{1}{2} \mathrm{ft} . \ldots \ldots \ldots \ldots$ I 75

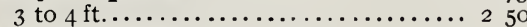

atropurpureum (Blood-leaf)-

I 8 to 24 in. .................. I 50

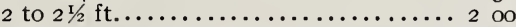

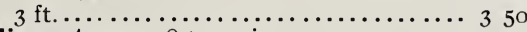

dissectum. I 8 to $24 \mathrm{in} . \ldots \ldots \ldots \ldots \ldots$ I 50

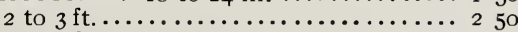

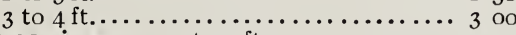

sanguineum. 2 to $3 \mathrm{ft} \ldots \ldots \ldots \ldots \ldots \ldots, 2$ oo

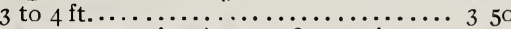

roseum marginatum. I 8 to 24 in..... I 50

Magnolia. Each tree furnished with ball of earth; well budded.

Soulangeana. 3 to $4 \mathrm{ft} . \ldots \ldots \ldots \ldots \ldots$ I oo 4 to $5 \mathrm{ft} . \ldots \ldots \ldots \ldots \ldots \ldots \ldots \ldots \ldots \ldots \ldots$ I 75

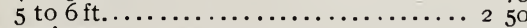

speciosa. 3 to 4 tt................... I 75

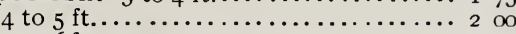

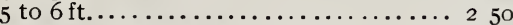

Stellata (Halleana). 2 to $3 \mathrm{ft} . \ldots \ldots \ldots$ I 50

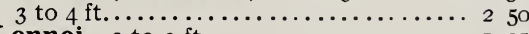
Lennei. 2 to $3 \mathrm{ft} . . \ldots \ldots \ldots \ldots \ldots \ldots \ldots$ I 25 4 to $5 \mathrm{ft} \cdot \ldots \ldots \ldots \ldots \ldots \ldots \ldots \ldots \ldots \ldots \ldots \ldots \ldots \ldots \ldots \ldots$ I 75 conspicua. $3 \mathrm{ft} . \ldots \ldots \ldots \ldots \ldots \ldots \ldots, 3$. Mulberry, Weeping $\ldots \ldots \ldots \ldots \ldots \ldots \ldots \ldots$ I

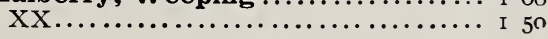

Per io

$\$ 5$ oo

8 oo

8 oo

500
600

5 oo

850

IO 00

I5 00

4 oo

600

I0 00

I5 00

4 OO

400

IO $\infty$

I2 50

I 250

6 oo

เo 00

400

5 oO

400
600

500

8 oo

6 oo

8 oo

600

I 200

2500

IO 00

6 oo

8 oо

I 300

I 80

750

I3 00

IO 00

600

I2 00

600
900

I5 00

$20 \mathrm{OO}$

I3 $\mathrm{Co}$

I 7 OO

I2 00

2000

I 200

750

I 5 Oo

2000

I5 00

I 750

2000

I2 00

2300

I0 00

I5 00
Each

Oak, Pin (Quercus palustris). 6 to $8 \mathrm{ft} . \$ \mathrm{I}$ oO 8 to Io $\mathrm{ft} . \ldots \ldots \ldots \ldots \ldots \ldots \ldots \ldots \ldots$ I 25 Io to $12 \mathrm{ft} \ldots \ldots \ldots \ldots \ldots \ldots \ldots \ldots \ldots \ldots$....................... 75 to 6 oo

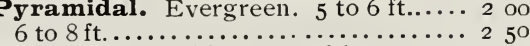

Concordia. Golden. 5 to $6 \mathrm{ft} \ldots \ldots \ldots$..... I 75

6 to $8 \mathrm{ft} . \ldots \ldots \ldots \ldots \ldots \ldots \ldots \ldots \ldots \ldots \ldots \ldots \ldots \ldots$. $5^{\circ}$ autumn foliage; superb. 4 to $5 \mathrm{ft}$.. I oo

6 to $8 \mathrm{ft} \ldots \ldots \ldots \ldots \ldots \ldots \ldots \ldots \ldots \ldots \ldots \ldots \ldots \ldots \ldots \ldots$ I 25

Osage Orange (Maclura)2 to $3 \mathrm{ft} . . . . . . . \ldots \ldots \ldots . .$. per Ioo, $\$$ Io. 5 to $6 \mathrm{ft} . \ldots \ldots \ldots \ldots \ldots \ldots \ldots \ldots \ldots \ldots$ I 00

Paulownia (Empress Tree). 6 to $8 \mathrm{ft}$... I oo

Peach, Double-flowering. 3 to $4 \mathrm{ft} . . . \quad 50$ 5 to $6 \mathrm{ft} . \ldots \ldots \ldots \ldots \ldots \ldots \ldots \ldots \ldots$ I oo

Plane, Oriental. 6 to $8 \mathrm{ft} \ldots \ldots \ldots \ldots \ldots$, 50 8 to Io $\mathrm{ft}$; I to I $1 / 2 \mathrm{in}$. diam......... 75 Io to $12 \mathrm{ft}$; I $1 / 2$ to $2 \mathrm{in}$. diam......... I 25 I 2 to $14 \mathrm{ft}$; 2 to $2 \mathrm{I} / 2 \mathrm{in}$. diam........... I 75

Poplar, Carolina. 8 to io $\mathrm{ft}$... IOo, $\$ 20 . .40$

Io to I2 ft.............

Lombardy. 6 to $8 \mathrm{ft} . . .$. " " $\$ 20 . . \quad 35 \quad 250$

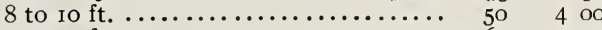

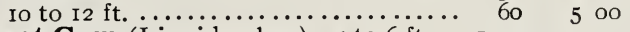

Sweet Gum (Liquidambar). 5 to $6 \mathrm{ft}$.... I oo

Whorn, Double Pink. 4 to $5 \mathrm{ft} . . . . . .6$ 6o

Double White. 4 to $5 \mathrm{ft} \ldots \ldots \ldots \ldots \ldots$...... 60

Scarlet (Crategus coccinea), 4 to $5 \mathrm{ft}$. 60

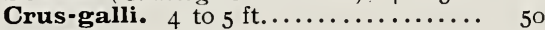

Tulip Tree. 6 to $8 \mathrm{ft}$............... 75

Virgilia (Yellow Wood). 5 to $6 \mathrm{ft.......} \mathrm{I} \mathrm{oo}$

Willow, Rosemary-leaved. On own roots. Low-branched. 4 to $5 \mathrm{ft} . .$. .

Rosemary-leaved. 5 to $6 \mathrm{ft}$., topgrafted ..................... I oo

Other varieties. 6 to $8 \mathrm{ft} . \ldots \ldots \ldots \ldots$. 50 8 to ro ft. ....................... 75

$5 \mathrm{co}$

5 oo

5 .

600

750

600

900

400

500

\section{EVERGREENS}

All our Evergreens have been transplanted several times, so that they have developed ample fibrous roots to transfer in safety from our grounds to yours. We take great care, also, to burlap the roots in a large ball of earth. Among many species we offer are some of the cheaper sorts for screens and hedges; also, choice specimens of the more rare and beautiful Colorado Blue Spruce, Oriental Spruce, Nordmann's Fir, White Pine, Mugho Pine, Swiss Stone Pine, Japanese Umbrella Pine, Arborvitæ, Hemlock, netinosporas, Junipers, etc.

We invite correspondence with those desiring to plant Evergreens, and offer information as to proper time and method of handling the different species. Special estimates for large numbers. See General Catalogue.

Arborvitae, American- Each Per Io I8 to 24 in............... per 1oo, \$10..\$O 20 \$I 50 2 to $3 \mathrm{ft} \ldots \ldots \ldots \ldots \ldots \ldots \ldots$ " \$I $8 . . \quad 25 \quad 250$

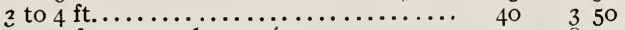
4 to $5 \mathrm{ft}$.; extra heavy ............... I । 8 o 8 oo globosa (Globe-headed). I 8 to 24 in... $50 \quad 4$ oo 2 to $3 \mathrm{ft}$; 30 in. diam............... I oo 8 oo

Hovey's Golden. is to 24 in........... I oo 8 oo

Pyramidal. 3 to $4 \mathrm{ft} . \ldots \ldots \ldots \ldots \ldots \ldots$. 1 I 25 io 00

4 to $5 \mathrm{ft} \ldots \ldots \ldots \ldots \ldots \ldots \ldots \ldots \ldots \ldots \ldots \ldots \ldots$ I 50 I 3 oo

George Peabody. I 8 to 24 in.......... I o 750

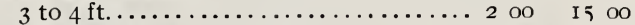

Vervaeneana. 3 to $4 \mathrm{ft} \ldots \ldots \ldots \ldots \ldots$ I 25 Io

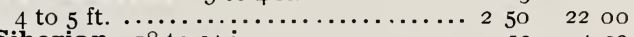

Siberian. I 8 to 24 in............. so 400 2 to $3 \mathrm{ft} . \ldots \ldots \ldots \ldots \ldots$ per Joo, $\$ 40 .$. 6o $\quad 600$

Fir, Nordmann's Silver. 3 to $3 \frac{1}{2} \mathrm{ft} \ldots 350$ 30 300 $3 \frac{1}{2}$ to $4 \mathrm{ft}$., $3 \mathrm{ft}$. broad ............... 4 oo 35 oo

Hemlock. See Spruce.

Juniper, Douglas Golden. 12 to $\mathrm{I}_{5}$ in... 353 oo

Irish. I 8 to 24 in................... 30 2 50

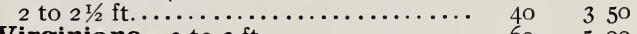

Virginiana. 2 to $3 \mathrm{ft} \ldots \ldots \ldots \ldots \ldots \ldots \ldots$, bo 5 oo 3 to $4 \mathrm{ft} . \ldots \ldots \ldots \ldots \ldots \ldots \ldots \ldots$ I 00,8 oo 4 to $5 \mathrm{ft} . \ldots \ldots \ldots \ldots \ldots \ldots \ldots \ldots \ldots \ldots$ I 50 
EVERGREENS, continued Each

Juniper, Savin. 18 to $24 \mathrm{in} . . . \ldots \ldots \ldots$.... 50

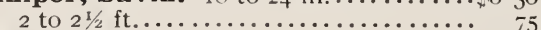

Swedish. I 2 to 18 in................. 30

2 to $2 \mathrm{r} / 2 \mathrm{ft} \ldots \ldots \ldots \ldots \ldots \ldots \ldots \ldots \ldots \ldots$ 50

Japanese Umbrella Pine (Sciadopitys

verticillata). This is, without doubt,

the greatest acquisition from Japan in

the line of evergreens, and is destined to

become as popular as the Colorado Blue

Spruce. Hardy to Maine. 2 to $2 \% \mathrm{ft} . .2250$

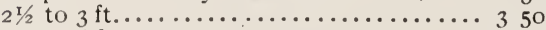

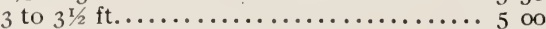

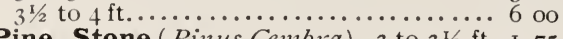

Pine, Stone (Pinus Cembra). 3 to $3^{1 / 2} \mathrm{ft}$. I 75

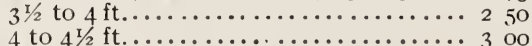
Bhotan (P. excelsa). 2 to $3 \mathrm{ft} \ldots \ldots \ldots$.... 75

3 to $4 \mathrm{ft}$; heavy ................. I 25

Austrian. 3 to $4 \mathrm{ft} . \ldots \ldots \ldots \ldots \ldots \ldots$.

4 to $5 \mathrm{ft}$. heavy specimens, $\{\ldots \ldots \ldots 2$ oo

5 to $6 \mathrm{ft}$. $\}$ transplanted $1905\{\ldots \ldots \cdots 2=0$

Mugho (Mountain) 12 to 18 in........ 50

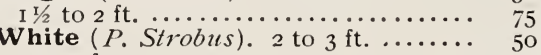

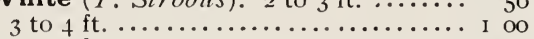

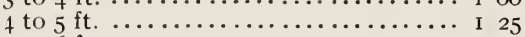

5 to $6 \mathrm{ft} . \ldots \ldots \ldots \ldots \ldots \ldots \ldots \ldots \ldots \ldots \ldots$ I 75

Fetinispora filifera. $3 \mathrm{ft} \ldots \ldots \ldots \ldots \ldots, 250$

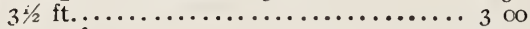

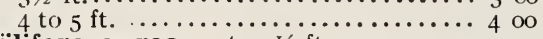

filifera aurea. I to $I \frac{1}{2} \mathrm{ft} \ldots \ldots \ldots \ldots \ldots$ I 75

gracilis. $\mathrm{I} / 2$ to $2 \mathrm{ft} . \ldots \ldots \ldots \ldots \ldots \ldots \ldots$ I 25

yisifera a urea. 2 to $3 \mathrm{ft} . \ldots \ldots \ldots \ldots$ I 75

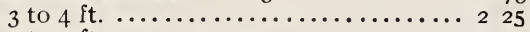

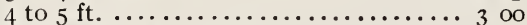

plumosa. $2 \frac{1 / 2}{2}$ to $3 \mathrm{ft} \ldots \ldots \ldots \ldots \ldots \ldots \ldots$ I 25

3 to $4 \mathrm{ft} . \ldots \ldots \ldots \ldots \ldots \ldots \ldots \ldots \ldots \ldots \ldots \ldots$ I 75

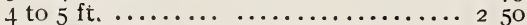

plumosa aurea. 2 to $2 \frac{1}{2} \mathrm{ft} \ldots \ldots \ldots \ldots$. I 00

$21 / 2$ to $3 \mathrm{it} ; \mathrm{I} 1 / 2$ to $2 \mathrm{ft}$. diameter ....... I 75

Heavy, sheared. 3 to $3^{1 / 2} \mathrm{ft}$; 2 to $2 \frac{1}{2}$

$\mathrm{ft}$. dianteter.................... 250

obtusa. $11 / 2$ to $2 \mathrm{ft} \ldots \ldots \ldots \ldots \ldots \ldots \ldots \ldots \ldots$ I

obtusa nana. 12 to 15 in............ I 00

obtusa nana aurea. I to $I \frac{1}{2} \mathrm{ft} . .$. . I 50

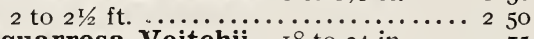

squarrosa veitchii. is to 24 in ..... 75

2 to $2 \frac{1}{2} \mathrm{ft} . \ldots \ldots \ldots \ldots \ldots \ldots \ldots \ldots \ldots$ I 00

3 to $4 \mathrm{ft}$., slieared...................... 250

4 to $5 \mathrm{ft}$., sheared ................. 350

Spruce, Alcockiana. 2 to $3 \mathrm{ft} . \ldots \ldots \ldots 250$

3 to $4 \mathrm{ft}$, specimens ................ 350

concolor. 2 tu $3 \mathrm{ft} . \ldots \ldots \ldots \ldots \ldots \ldots$.......... I 75

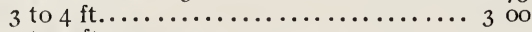

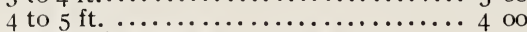

Douglasii glauca. 4 to $5 \mathrm{ft} \ldots \ldots \ldots \ldots$. 75

5 to $6 \mathrm{ft} . \ldots \ldots \ldots \ldots \ldots \ldots \ldots \ldots \ldots \ldots \ldots \ldots \ldots \ldots \ldots \ldots$ I 50

Hermlock ( $\mathrm{T}$ suga $)$. 2 i 2 to 18 in.; transplanted............... per Ioo, $\$ 25$.

I 8 to 24 in.............. per I0o, $\$ 40 .$.

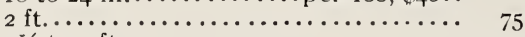

$21 / 2$ to $3 \mathrm{ft} . \ldots \ldots \ldots \ldots \ldots \ldots \ldots \ldots \ldots$ I

3 to $4 \mathrm{ft} . \ldots \ldots \ldots \ldots \ldots \ldots \ldots \ldots \ldots \ldots \ldots$ I 25

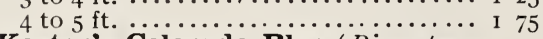

Koster's Colorado Blue (Picea pungens glauca Kosteri). No evergreen is more in demand than this. Ours are the genuine Koster variety grafted,--worth a dozen seedlings. Seeing the splendid color of our trees, one customer ordered 200 of them.

$\mathrm{I} x / 2$ to $2 \mathrm{ft} \ldots \ldots \ldots \ldots \ldots \ldots \ldots \ldots \ldots \ldots \ldots \ldots \ldots \ldots \ldots \ldots \ldots \ldots \ldots$

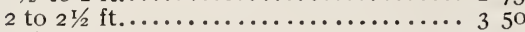

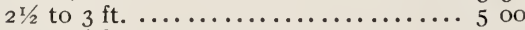

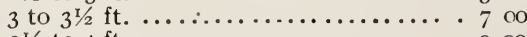

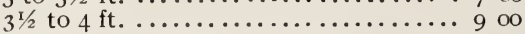

Koster's Weeping ( $P$. pendula). This is the greatest acquisition in conifers in some time. All the branches, even the young shoots, are all drooping.

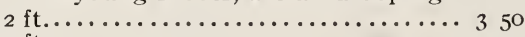

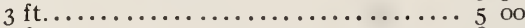

$4 \mathrm{ft} . \ldots \ldots \ldots \ldots \ldots \ldots \ldots \ldots \ldots \ldots, \ldots+\ldots$
Per io $\$ 400$

250

400

1500 2300

6 oo

10 oo

I0 00

1500

2000

4 oo

450

750

IO 00

2250

2750

10 oo

$15 \mathrm{Co}$

2000

10 00

15 oo

2250

8 oo

1500

$225^{\circ}$

750

$\begin{array}{rr}7 & 50 \\ 12 & 50\end{array}$

6 oo

8 oo

1500 2500

600

1300

$6 \mathrm{oO}$

750

I0 00

1500

2500 3000

4500

6500
8500

Extra size Trees and Shrubs, page 8

2 to $3 \mathrm{ft}$

3 to $4 \mathrm{ft}$

4 to $5 \mathrm{ft}$.
5 to $6 \mathrm{ft}$. plication.
Spruce, Norway. I 8 to 24 in......... Each Per 10 per I00, \$20..\$o 30

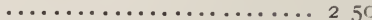

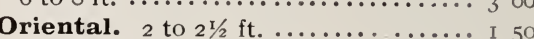

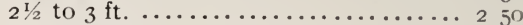

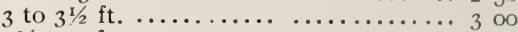

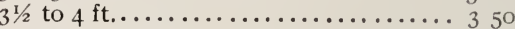

White. 2 to $3 \mathrm{ft} . \ldots \ldots \ldots \ldots \ldots \ldots$. I 00

Yew, English (Taxus baccata)-

$\mathrm{I} 1 / 2$ to $2 \mathrm{ft} . \cdots \cdots \cdots \cdots \cdots \cdots \cdots \cdots \cdots, 40$

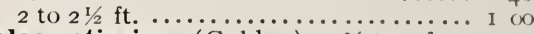

elegantissima (Golden). $I^{1 / 2}$ to $2 \mathrm{ft}$... I 50

Irish $(T$. fastigata $) .3 \mathrm{ft} . \ldots \ldots \ldots \ldots \ldots, 2$ oo

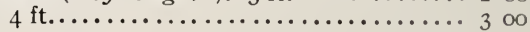

\section{EVERGREEN SHRUBS, HARDY}

RHODODENDRON. We offer all bushy and well-budded, field-grown plants, from a celebrated English grower and they should not be compared with Holland-grown plants. Prices are as follows:

I 8 to 24 in................... \$I $25 \$ \$ 10$ oo

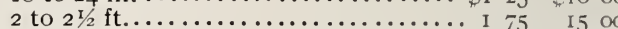

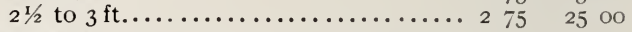

Kalmia (Mountain Laurel). Our Kalmias are bushy plants, nursery-grown, dug with ball.

I5 to 18 in.............. per I0o, \$50.. $75 \quad 600$ I $1 / 2$ to $2 \mathrm{ft} . . . \ldots \ldots \ldots \ldots$ " $60 . .$. I $00 \quad 900$ Collected Rhododendrons and $\mathrm{Kal}-$ mias, in car-load lots, priced on ap-

Aucuba Japonica. 2 to $2 \mathrm{x} / 2 \mathrm{ft} . \ldots . \ldots$.... I 25 IO 00 $2 \frac{1 / 2}{2}$ to $3 \mathrm{ft} . \ldots \ldots \ldots \ldots \ldots \ldots \ldots \ldots \ldots \ldots$ I 75 in 00

Azalea amoena (Evergreen Azalea). I2 to 15 in. high; 12 to 15 in. diam.... per $100, \$ 40.50 \quad 450$ 15 to 18 in. high; 15 to 18 in. diam... per $100, \$ 60 \ldots \quad 75$

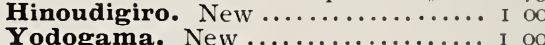

Boxwood Trees. Pyramid shape- Each 30 to $36 \mathrm{in.} \mathrm{high;} \mathrm{i5} \mathrm{in.} \mathrm{diam.} \mathrm{at} \mathrm{base....... \$ 2} 50$ 36 to $42 \mathrm{in}$. high; 15 to $\mathrm{I} 8 \mathrm{in}$. diam. at base ... 300 42 to 48 in. high; 18 to 20 in. diam. at base ... 350 48 to 50 in. high; 2 to $3 \mathrm{ft}$. diam. at base.... 450 54 to $60 \mathrm{in.} \mathrm{high;} 3 \mathrm{ft}$. diam. at base ........ 550

Boxwood Trees. Standard or tree-shaped-

Stem 30 in. high; diam. of crown 14 to 16 in.. 200 Stem 30 in. high; diam, of crown 16 to 18 in.. 250 Stem 30 in. high; diam. of crown 18 to 22 in.. 3 oo Stem 30 in. high; diam. of crown 22 to 24 in.. 350 Stem 30 in. high; diam. of crown 24 to $30 \mathrm{in.} 400$

Bushes. Untrimmed. I ft. .......\$2 for I0.. 25

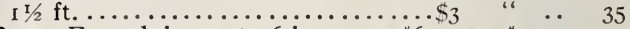

Box. For edging 4 to 6 in. ... I0o $\$ 6,1,000 \$ 50$.

Mahonia. This most beautiful evergreen is very scarce. We offer bushy plants. Each Per io I 2 to 18 in. high.......... per IOO, \$15.\$O $25 \$ 200$ I 8 to 24 in. high........." $\$ 25 \ldots 35 \quad 300$

Leucothoe Catesbaei. 12 to 18 in...... $25 \quad 200$

\section{SHRUBS IN TREE FORM}

Each Per Io

Althaea. 4 to $5 \mathrm{ft} . \ldots \ldots \ldots \ldots \ldots \ldots \ldots$. 75

Azalea mollis. 4 to $5 \mathrm{ft}$.; 20 to 60 buds. $\$$ I to 150

Caragana arborescens ............. I o

Forsythia................... $\$$ I to I 50

Hydrangea. 4 to $5 \mathrm{ft} \ldots \ldots \ldots \ldots \ldots \ldots \ldots, 5^{\circ}$

Laburnum ...................... 75

Purple Fringe. 4 to $5 \mathrm{ft} . \ldots \ldots \ldots \ldots \ldots$ I 00 5 to $6 \mathrm{ft} . \ldots \ldots \ldots \ldots \ldots \ldots \ldots \ldots \ldots \ldots \ldots$ I 25

Viburnum plicatum. 4 to 5 it........... I 25

Wistaria..................... 1 to 300 


\section{HARDY VINES}

Actinidia polygama................ \$0 $35 \$ 250$ 3 -yr., heavy........................ $5^{\mathrm{S}} \quad 500$

Akebia quinata .................... $25 \quad 200$

Ampelopsis quinquefolia ( V i rginia Creeper) . ........... per 100, \$12..

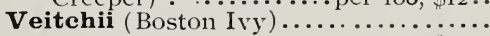
3-yr., extra .............per IOO, $\$ 12 \ldots$ 2 -yr., first-class $\ldots \ldots \ldots \ldots$ per Ioo, $\$ 8$. .

Aristolochia (Dutchman's Pipe) ..........

Celastrus scandens ................... $\underset{X X X}{X \ldots \ldots \ldots \ldots \ldots \ldots \ldots \ldots \ldots}$

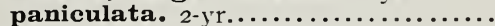

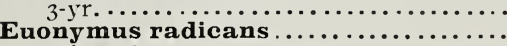
variegata

Hedera (English Ivy). I $1 / 2$ to $2 \mathrm{ft}$.. IOO. $\$$ IO.. 3 to $4 \mathrm{ft}$.. heavy ........... per Ioo, $\$ 20$. Honey suckle .............. per Ioo, \$1 $2 .$.

Kudzu vine (Pueraria)...................

Periploca Graeca

Tecoma

Wistaria, Chinese purple. Heavy Plants White

magnifica. 4 to $5 \mathrm{ft} \ldots \ldots \ldots \ldots \ldots \ldots \ldots$ I

multijuga. 4 to $6 \mathrm{ft} . \ldots \ldots \ldots \ldots \ldots \ldots$. I 00

\section{FLOWERING SHRUBS}

Five at ten rate, fifty at hundred rate

Almond, Dwarf Double Red. 2 to $3 \mathrm{ft}$...\$0 25

Aralia pentaphylla. 2 to $3 \mathrm{ft}$............ 25

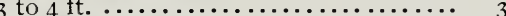

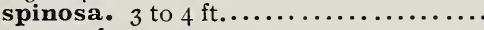
4 to $5 \mathrm{ft}$

Althaea, Named Varieties. 2 to $3 \mathrm{ft}$. Variegated-leaved. i 8 to 24 in. . . 3 . totus alba. 2 to $3 \mathrm{ft} . \ldots \ldots \ldots \ldots \ldots \ldots \ldots$

Berberis Thungbergii. I 2 to I 8 in. Ioo, $\$ 8$. is to 24 in................ per Ioo, \$10. 2 to $3 \mathrm{ft} . \ldots \ldots \ldots \ldots \ldots$ per $100, \$ 15$.

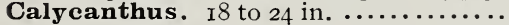

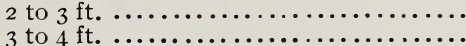

Clethra alnifolia. 2 to $2 \frac{1}{2} \mathrm{ft} . \ldots \ldots \ldots . .$. $2 \mathrm{ft}$; bushy $\ldots \ldots \ldots \ldots \ldots \ldots \ldots \ldots \ldots$

Caragana arborescens. 2 to $3 \mathrm{ft} . . . .$. .

Caryopteris. 2 to $3 \mathrm{ft} . \ldots \ldots \ldots \ldots \ldots \ldots$.

Cornus sanguinea. 2 to $3 \mathrm{ft} . \ldots \ldots \ldots \ldots$. 3 to $5 \mathrm{ft}$.

Spaethi. 2 to $3 \mathrm{ft} . \ldots \ldots \ldots \ldots \ldots \ldots \ldots$

Daphne Mezereum. Red. I 8 in. ......... White. 18 in...

Deutzia crenata. Double pink. 2 to $3 \mathrm{ft}$

Pride of Rochester. 2 to $3 \mathrm{ft} . . . . . .$.

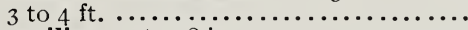

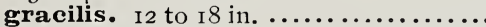

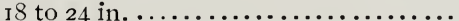
Lemoinei. I 8 to 24 in. $\ldots \ldots \ldots \ldots \ldots \ldots \ldots$
2 to $3 \mathrm{ft}$.

Elaeagnus longipes. 2 to $3 \mathrm{ft} . . . \ldots \ldots$.

Elder, Golden-leaved. 2 to $3 \mathrm{ft}$..........

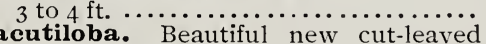
acutiloba. Beautiful new cut-leaved Elder. 2 to $3 \mathrm{ft} . \ldots \ldots \ldots \ldots \ldots \ldots \ldots \ldots \ldots \ldots$

Fern-leaved. 2 to $3 \mathrm{ft} . \ldots \ldots \ldots \ldots \ldots \ldots$

Exochorda (Pearl Bush). 2 to $3 \mathrm{ft}$.......

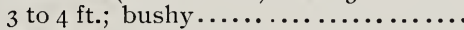

Forsythia. 2 to $3 \mathrm{ft} \ldots \ldots \ldots \ldots \ldots \ldots \ldots \ldots$ 3 to $4 \mathrm{ft} . \ldots \ldots \ldots \ldots \ldots \ldots \ldots \ldots \ldots \ldots \ldots$

Filbert, Purple-leaved. 2 to $3 \mathrm{ft}$...........

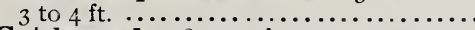

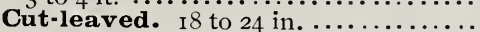

Hydrangea paniculata grandiflora... 2 to $3 \mathrm{ft}$; heavy $\ldots \ldots \ldots \ldots \ldots \ldots \ldots \ldots$ 3 to $4 \mathrm{ft}$; heavy ...................

Tree Form. 4 to $5 \mathrm{ft} . \ldots \ldots \ldots \ldots \ldots \ldots \ldots$

Hypericum Moserianum. I 8 to 24 in..
20 I 50
Each Per 10

Honeysuckle (Upright). 2 to $3 \mathrm{ft} \ldots . . \ldots$... 25 \$2 00

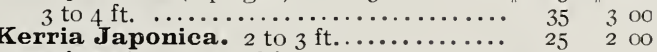

variegata. I2 to 18 in............... $25 \quad 2$ oo

Lilaes. Our list of Lilacs is unsurpassed. it includes the new double and single varieties of exquisite shades and very large panicles.

Named Varieties.

Persian and Common

$60 \quad 5$ o०

$30 \quad 250$

$35 \quad 3$ oo

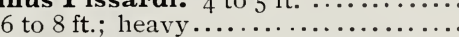

Purple Fringe (Rhus Cotinus). 2 to $3 \mathrm{ft}$. 3 to $4 \mathrm{ft}$.

Rhodoty pus (White Kerria). 2 to $3 \mathrm{ft}$.... Privet, California. $2 \frac{1}{2}$ to $3 \mathrm{ft}$............ per $\mathrm{I}, \mathrm{000}, \$ 30$. 3 to $4 \mathrm{ft} . \ldots \ldots \ldots \ldots \ldots \ldots$ per $\mathrm{I}, 000, \$ 60 .$.

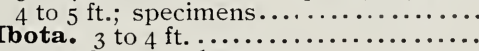
4 to $5 \mathrm{ft}$.; very heavy

Raspberry, Flowering. 2 to $3 \mathrm{ft}$............. Spiraea, Anthony Waterer. I 8 to 24 in.

Billardii. 2 to $3 \mathrm{ft} . \ldots \ldots \ldots \ldots \ldots \ldots \ldots$.

opulifolia aurea. 2 to $3 \mathrm{ft} . \ldots \ldots \ldots \ldots$ 3 to $4 \mathrm{ft}$.

Thunbergii. 2 to $2 \frac{1}{2} \mathrm{ft}$.

Van Houttei. 2 to $3 \mathrm{ft}$.

Sumac, Cut-leaved (Rhus glabra lacin-

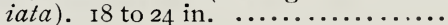
3 to $4 \mathrm{ft} . \ldots \ldots \ldots \ldots \ldots \ldots \ldots \ldots \ldots \ldots \ldots \ldots . . . \ldots \ldots$. 2 to $3 \mathrm{ft} . \ldots \ldots \ldots \ldots \ldots \ldots \ldots \ldots \ldots \ldots \ldots \ldots$

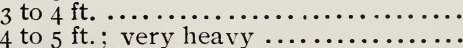
4 to $5 \mathrm{ft}$; very heavy $\ldots \ldots \ldots \ldots \ldots \ldots$ 3 to $4 \mathrm{ft}$; heavy ..................... Others same prices as Tomentosa.

Symphoricarpus vulgaris. 2 to $3 \mathrm{ft}$.... racemosus. 2 to $3 \mathrm{ft} . \ldots \ldots \ldots \ldots \ldots$. Syringa coronarius. 2 to $3 \mathrm{ft} \ldots \ldots \ldots \ldots$
Gordonianus. 2 to $3 \mathrm{ft} . \ldots \ldots \ldots \ldots \ldots$

Golden-leaved. I 2 to 18 in.............. I 8 to 24 in.

speciosa

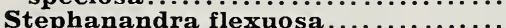

Styrax Japonica. 2 to $3 \mathrm{ft} . \ldots \ldots \ldots \ldots \ldots$ 3 to $4 \mathrm{ft}$.

Tamarix. 2 to $3 \mathrm{ft} . \ldots \ldots \ldots, \ldots \ldots \ldots, \ldots$

Weigelas. 2 to $3 \mathrm{ft}$.

\section{CHOICE FRUITS}

Extra sizes on application Each Per ro

Apples. 5 to $7 \mathrm{ft}$.; first-class........... \$0 $35 \quad \$ 250$

Cherries. 5 to $7 \mathrm{ft}$; first-class ........... 50 4 oo

Pears, Standard. 5 to $7 \mathrm{ft}$.; first-class.. $50 \quad 4$ oo

Dwarf. 3 to $4 \mathrm{ft}$.; first-class.............. 35 3 3 oo

Plums. 5 to $7 \mathrm{ft}$.; first-class............. 50 4 oo

A few large sizes of Japanese .......... I o

Peaches, Apricots and Nectarines.... $25 \quad 2$. 20

Quinces. 4 to $6 \mathrm{ft}$.; first-class........... 50 4 oo

Grapes. 2 -yr. ........................ $25 \quad 2$ oо

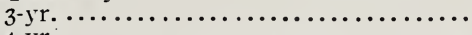

ackberries, and Blackeap and $\mathbf{R e d}$ Raspberries per doz., 50 cts.; per ioo, $\$ 3 .$.

Blackberry, Erskine Park Seedless.

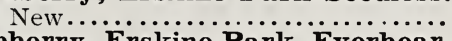

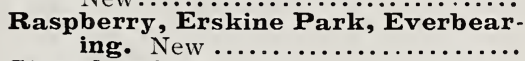

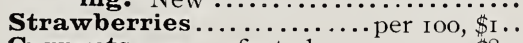

Currants. 2-yr.; first-class..per Ioo, $\$ 8 .$.

Perfection. New ........ per Ioo, \$15..

Gooseberries, Industry - 2-yr. ; firstclass...............................

Columbus
Wyndam Industry. ${ }^{\prime} \ldots \ldots \ldots \ldots \ldots$
New English Heavy imported, 3 -yr. plants ....... Asparagus .......................................

Rhubarb.... per doz.. \$I.50; per Ioo, $\$ 8$. 


\section{PLANTING PLANS AND OUR SUPERIOR STOCK}

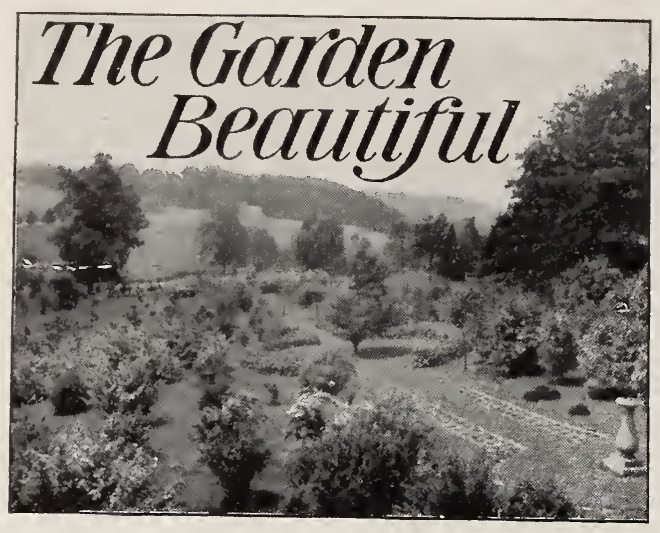

requires proper care and cultivation, but equally depends upon intelligent selection of varieties and harmonious design in planting. Neglect of any of these points will give a garden lacking in some element of beauty. We make a specialty of Designs for Suburban Grounds and have furnished plans for many of the most beautiful places near New York City. Planting designs we supply to distant customers uniformly give complete satisfaction,- - they are practical and easy of application.

We not only furnish first-class material at the proper season for the best results, but we are prepared to renovate old estates, make planung plans for new ones, and in many other ways assist our patrons to the highest development of their grounds. To those in the vicinity of New York we make a preliminary visit without charge. Those at a distance should send us a sketch of their grounds with dimensions, points of the compass, location of buildings, trees, etc.

From these data we make a plınting plan, drawn to scale, at a moderate cost. By so doing, our clients would save expense and disappointment, because, without expert advice, planters are apt to select material for planting which is either not hardy or will not thrive in a given location. Noreover, those not familiar with the ultimate sizes of trees, shrubs, etc., are apt to use two or three times the number required for the best effect. Nany buyers find our superb catalogue sufficient to help them in selecting material, for we have spared no pains to make it as helpful as possible, and are supplementing it by correspondence, answering inquiries and suggesting proper selections.

To those contemplating a large planting, we wish to call attention to the fact that we have filled some of the largest orders known among nurserymen. In the last four years we have supplied one large estate in this vicinity with over 26,000 trees, besides shrubs, bulbs, etc. The fact that this number of trees has been largely evergreens, which are more difficult to transplant than deciduous trees, is pretty good proof that our stock bears transplanting well.

From one of the most noted rosarians in the country we have received an order for as many as $\$ 1,200$ worth of rose plants at one time. We take especial pride in the fact that we delivered this spring, to the entire satisfaction of our customer, nearly $\$ 2$, oo worth of stock from all departments. Although there are well-known nurseries much nearer home, the order came to us because of the way we handled a previous order of nearly $\$ 4$, , oo.

S. G. HARRIS, M.S., Tarrytown, N. Y.

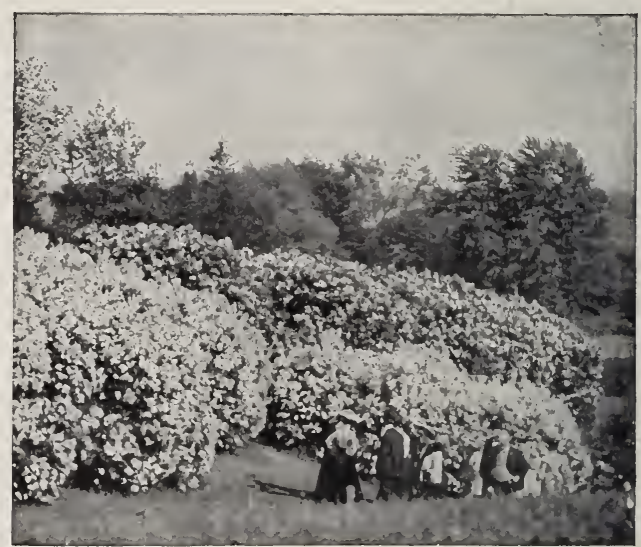

